\title{
17
}

\section{Skin Mechanobiology and Biomechanics: From Homeostasis to Wound Healing}

\author{
Maria G. Fernandes ${ }^{* \dagger}$, Lucilia P. da Silva*, ${ }^{*}$, and Alexandra P. Marques*,†,* \\ *I3Bs-Research Institute on Biomaterials, Biodegradables and Biomimetics of University of Minho, Headquarters \\ of the European Institute of Excellence on Tissue Engineering and Regenerative Medicine, University of Minho, \\ Guimarães, Portugal ${ }^{\dagger}$ ICVS/3B's—PT Government Associate Laboratory, Guimarães, Portugal ${ }^{*}$ The Discoveries Centre \\ for Regenerative and Precision Medicine, Headquarters at University of Minho, Guimarães, Portugal
}

\subsection{INTRODUCTION}

The skin is the outmost and largest organ of the body constituting $6 \%-10 \%$ of the lean body mass. It is a layered tissue containing in total more than 20 different cell types that in a very coordinated way act to keep skin homeostasis and function. It is the first line of defense against the external environment, that is, external forces (tension, compression, and shear), external pathogens, temperature, and radiation. The outermost layer, epidermis, varies in thickness depending on its location and function. This layer consists of a stratified squamous epithelium of keratinocytes delimited by the basal membrane and contains melanocytes, Langerhans cells, and Merkel cells [1, 2]. The internal layer, dermis, is a connective tissue that represents most of the skin substance and structure. The dermis is composed of fibroblasts and extracellular matrix (ECM) enriched in collagen and elastin fibers and can be divided into two layers: the upper papillary and the thicker lower reticular dermis. The skin mechanical properties, strength, and elasticity are mostly owed to the composition and organization/orientation of the ECM in the dermis [3-5]. Lastly, beneath the dermis is the hypodermis, composed primarily of adipose cells used for fat storage, and is usually not regarded as part of the skin tissue.

Being a tissue constantly exposed to many external and endogenous factors, which disintegrate its structure and functions, skin requires intrinsic suitable mechanical properties that protect the body from suffering damage. While it is known that skin has high flexibility and is able to support large deformations, its mechanical properties are complex and difficult to describe or predict due to skin complexity. Moreover, the mechanical properties of skin not only differentiate between the different layers but also vary with skin anatomical region (heterogeneity), age, sex, pathology, body weight, and orientation (anisotropy) (Fig. 17.1). In addition to skin inherent biomechanics variability, the mechanical testing used to analyze skin biomechanics plays a pivotal role in the measurement [6-10]. Hence, it is not surprising that the evaluation of skin biomechanics has revealed inconsistent results.

The skin is a tensegrity tissue, and it is in passive tension at homeostasis. Once the mechanical properties of the skin are unable to support the external conditions or the tissue is removed, the skin tensegrity is compromised. After a breach, the skin responds with an orchestrated process to heal the wound and restore the integrity of the tissue. The wound healing process encompasses four interconnected and consecutive phases, namely, hemostasis, inflammation, proliferation, and remodeling. All of these phases are influenced by mechanical forces, and there is increasing evidence that mechanical influences regulate postinjury inflammation contributing to the closure of the wound [11] and the formation of fibrotic tissue $[12,13]$. Human skin, as well as skin cells, reacts to mechanical forces and converts mechanical cues to biochemical signals that are crucial to the way the wound healing progresses [12, 14]. While the homeostatic and wound cellular and biochemical milieus have been largely studied to create better cues for regeneration, skin mechanical environment has not been as explored. Moreover, most of this knowledge has been provided by in vitro studies assessing the effect of tension over skin cells [15-24]. Mechanical stimuli have also been evaluated 


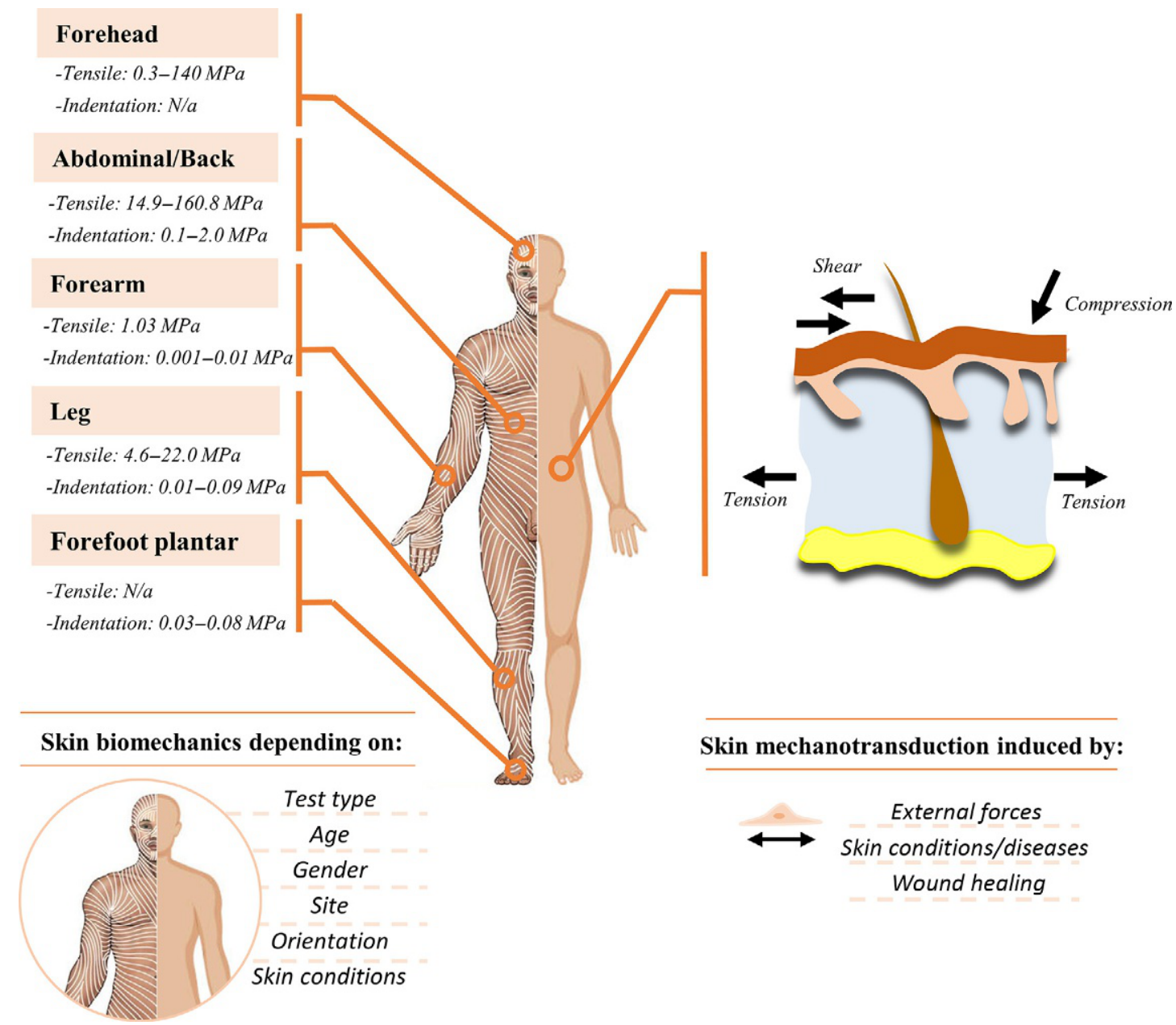

FIG. 17.1 Overview of human skin mechanical properties and schema of external mechanical forces that are transmitted across the skin tissue.

in vivo but mainly in rodent animal models that fail to represent skin biomechanics [25-27] and in pigs [28]. Thus, a better understanding of how healthy and wounded tissue deforms and how cells respond to this mechanical stress is critical for the creation of new therapies for scarless wound regeneration.

This chapter aims to elucidate the reader about skin biomechanics by focusing on the overall mechanical properties of the tissue and on its biomechanics. For this purpose, the main concepts and methodologies to measure skin mechanics as well as the mechanisms underlying skin mechanobiology and biomechanics are described. An overall analysis of this knowledge is presented, and a discussion on how it can be the basis to ameliorated wound healing approaches and relieve scarring through new therapies is provided.

\subsection{BIOMECHANICS IN THE CONTEXT OF THE SKIN}

As already mentioned the skin tissue is composed of different structural components, such as the collagen fibers ( $27 \%-39 \%$ by volume and $75 \%-80 \%$ of fat-free dry weight), elastin fibers $(0.2 \%-0.6 \%$ by volume and $4 \%$ of the fatfree dry mass), and glycosaminoglycans $(0.03 \%-0.35 \%$ by volume), in different combinations. Hence the properties of the skin are both dependent on the composition and their organizational direction [29]. Numerous studies were conducted over the last 40 years to characterize the mechanical behavior of the human skin. Most of them describe skin as a nonhomogeneous and anisotropic tissue with nonlinear and time-dependent mechanical behavior that can include viscoelastic response highly variable and sensitive to environmental conditions [4, 10, 30-32]. Accurate acknowledge of the skin structure and its constituents are important for determining its response to the different mechanical loads since each of these components has its own role in the mechanical properties of the skin tissue. Collagen (types I and III as the most prominent in human skin), as the main load-bearing and stiff component of 
the dermis, provides most of the mechanical strength of skin [33]; elastin fibers form a network in dermis and works like an energy storage device, bringing stretched collagen back to a relaxed position, which means they provide to the skin the ability to recoil after deformation [3]; and glycosaminoglycans, such as dermatan sulfate, hyaluronic acid, and chondroitin sulfate, provide to the skin their viscoelastic nature at low loads [34]. Glycosaminoglycans are covalently linked to peptide chains that form high-molecular-weight complexes called proteoglycans. The viscoelastic properties of connective tissue are strongly correlated with the type and the number of glycosaminoglycans [35].

Skin, as the outer shield of the human body, has often their mechanical integrity threatened and therefore needs to hold appropriate mechanical properties to respond correctly to the external mechanical forces. To understand the mechanical properties of skin, one must understand the main terms used to describe them. The following subsections highlight the basic definitions of the physics terms important to the understanding of the skin mechanics.

\section{Stress and Strain}

Most of the times materials are in a state of stress meaning that a force is being applied, and this will cause a change in its dimensions. Thus stress can be defined as the ratio of the applied force $F$ (in newtons, $\mathrm{N}$ ) to cross-sectional area $A_{0}$ (in square meters, $\mathrm{m}^{2}$ ) of a material. Depending on the force and the direction that is applied, three basic types of stress can be made on a material: tensile $(\sigma)$, compressive $(\sigma)$, and shear $(\tau)$ stress (Fig. 17.2).

Strain, the change in material dimensions produced by a force that varies on its nature (tensile or compressive $(\varepsilon)$, or shear $(\gamma)$ force), is calculated by the ratio of the change in length $(\Delta L)$ to the original length $\left(L_{0}\right)$. Strain is dimensionless and sometimes represented as a percent change. The relation between the applied force and strain, or their rates, allows the assessment of material mechanical properties.

\section{Elasticity, Inelasticity, and Viscoelasticity}

Materials display different mechanical behaviors when an external load is applied and then removed (Fig. 17.3). Elasticity describes the material ability to deform instantaneously when a load is applied and to return immediately to its original state once the load is removed. On the other hand, inelasticity is the property of a material that keeps it permanently deformed by a force, which means that the material does not return to the original configuration when unloaded, remaining in the deformed state. Inelastic materials included viscous (fluids) and plastic materials, while viscoelastic ones combine the characteristics of both elastic solids and viscous fluids when undergoing deformation [36]. The viscoelastic materials exhibit time-dependent strain showing a "fading memory." Such behavior can be linear (stress and strain are proportional) or nonlinear.

\section{Stiffness, Young's Modulus, and Strength}

Stiffness describes the property of a material to resist the deformation under applied loads. The stiffness of a material is commonly defined by Young's or elastic modulus $(E)$, determined by the slope of the linear region of a stressstrain curve when tested under tensile or compressive loads. Strength is a measure of the material resistance to failure by fracture or excessive deformation and can be defined as the maximum stress that the material supports before breaking. The strength of the materials varies with the nature of the applied force. For instance, there are materials with higher strength under compression but lower strength under tension.

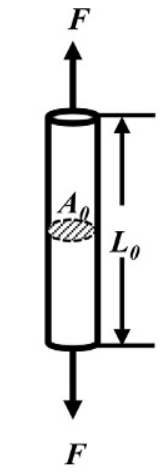

Tensile stress, $\sigma$

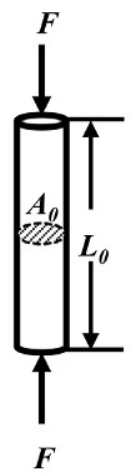

Compressive stress, $\sigma$

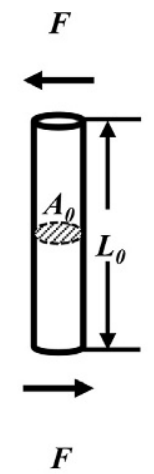

Shear stress, $\tau$

FIG. 17.2 Schematic description of the different types of applied stresses, expressed in newton per square meter $\left(\mathrm{N} / \mathrm{m}^{2}\right)$ or Pascal $(\mathrm{Pa})$, where $1 \mathrm{~Pa}=1 \mathrm{~N} / \mathrm{m}^{2}$ in the international system (SI). The units used for molecular, cell, or tissue levels are usually nanonewton per square micron $\left(\mathrm{nN} / \mu \mathrm{m}^{2}\right.$ ) or $\mathrm{kPa}\left(\right.$ where $\left.1 \mathrm{nN} / \mu \mathrm{m}^{2}=1 \mathrm{kPa}\right)$. 


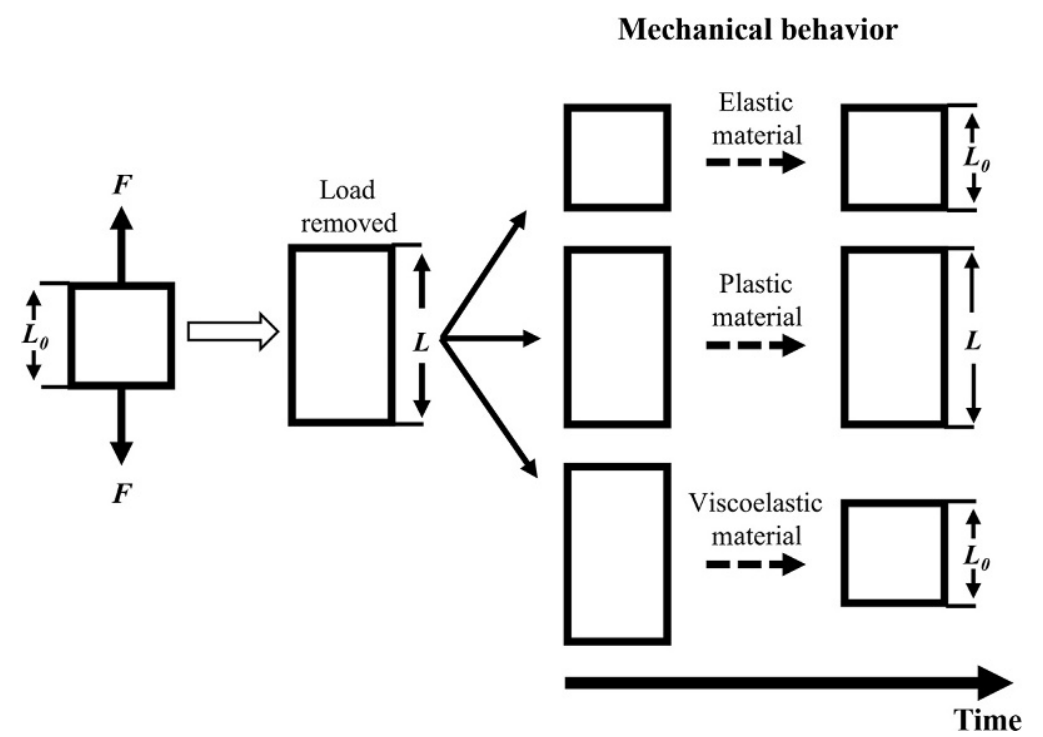

FIG. 17.3 Schematic representation of the different mechanical behavior along the time of materials subjected to a tensile load.

\section{Anisotropy and Nonhomogeneity}

Anisotropy is the property of being directionally dependent, which means that the physical properties of a material are different when measured along different axes $(\mathrm{x}, \mathrm{y}$, and $\mathrm{z})$. As opposed to anisotropy, isotropy means homogeneity in all directions. Nonhomogeneity means that the material is made of the different material throughout. Because nonhomogeneous materials vary from point to point, it is important to note that the measured mechanical properties are also influenced by the structural characteristics of the material and their microstructural constituents.

\subsubsection{Measuring Skin Mechanical Properties}

Several methods have been followed to determine the mechanical properties of whole skin tissue in response to various loading conditions. These methods have been generally applied in in vivo and ex vivo samples. The majority of the approaches use either uniaxial/biaxial tensile testing, compression, indentation, or suction, subsequently coupled to imaging techniques such as motion analysis and digital image correlation to map the strain distribution in the skin tissue $[9,37-42]$. Since skin mechanics is strongly dependent on active processes, the in vivo analyzes are the truly reliable methods to determine skin properties. Usually, a static or dynamic external force is applied on a specific area of the skin surface to provoke a stretch, compression, shear, or even torsion deformation and then assess the mechanical properties [38, 43-45]. However, these measurements can be restrictive since only small stresses can be applied and the boundary conditions cannot be fully controlled. In opposition, higher deformation along different skin directions can be applied in the ex vivo tests providing useful anisotropic data [46]. In addition, ex vivo experiments allow to conduct destructive tests and to obtain the skin mechanical behavior up to the failure point, as well as to analyze the skin layers' behavior separately.

\subsubsection{Tensile Testing}

Considering all of the mechanical tests that are performed in skin tissue, tensile testing is probably the most common one. This is because, in normal physiological conditions, the skin is under a state of tension even in the absence of external loading $[47,48]$. Tensile testing is performed by elongating a skin specimen under uniaxial or biaxial loading until failure. In uniaxial tests, the skin samples are tapered into a "dog bone" shape, while in the biaxial tests, the samples are cut into a square shape (Fig. 17.4A). From the representation of the results into a stress/strain curve, a variety of mechanical properties such as Young's modulus (stiffness), yield stress, ultimate stress, the ultimate tensile strength, and energy at failure can be extracted (Fig. 17.4B).

Some studies have shown that skin tissue under uniaxial tension experience three distinct stages (I, II, and III) (Fig. 17.5) [4, 49-51]. These stages are mainly related to the structural response of the dermal collagen and elastin fibers. In the first stage (up to $30 \%-40 \%$ of strain), the skin tissue is gradually stretched, and most of the mechanical response is carried out through the elastin fibers and the proteoglycan matrix. At this stage, the contribution of the crimped collagen fibers can be neglected [52]. When the skin is stretched to high strain levels (Stage II), the crimped collagen 


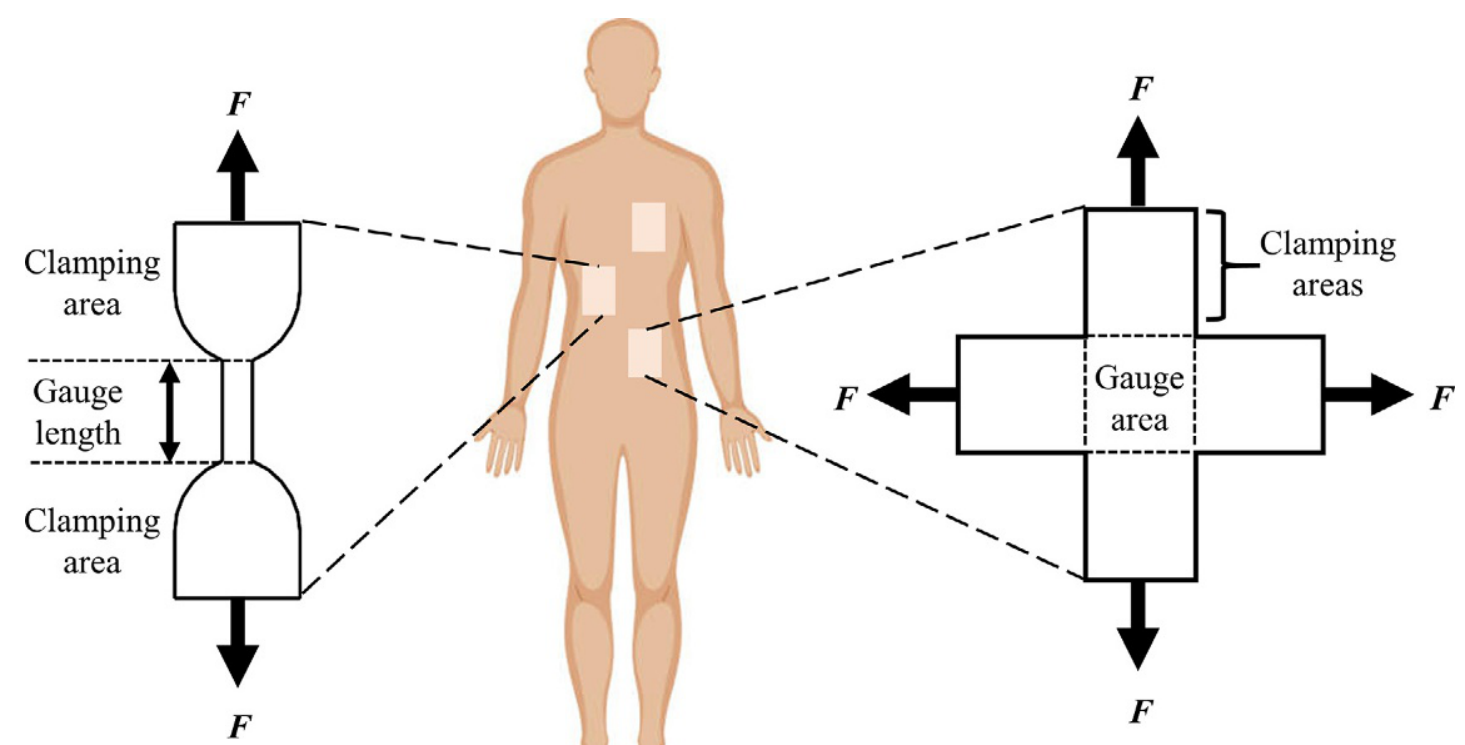

(A) Uniaxial test

Biaxial test

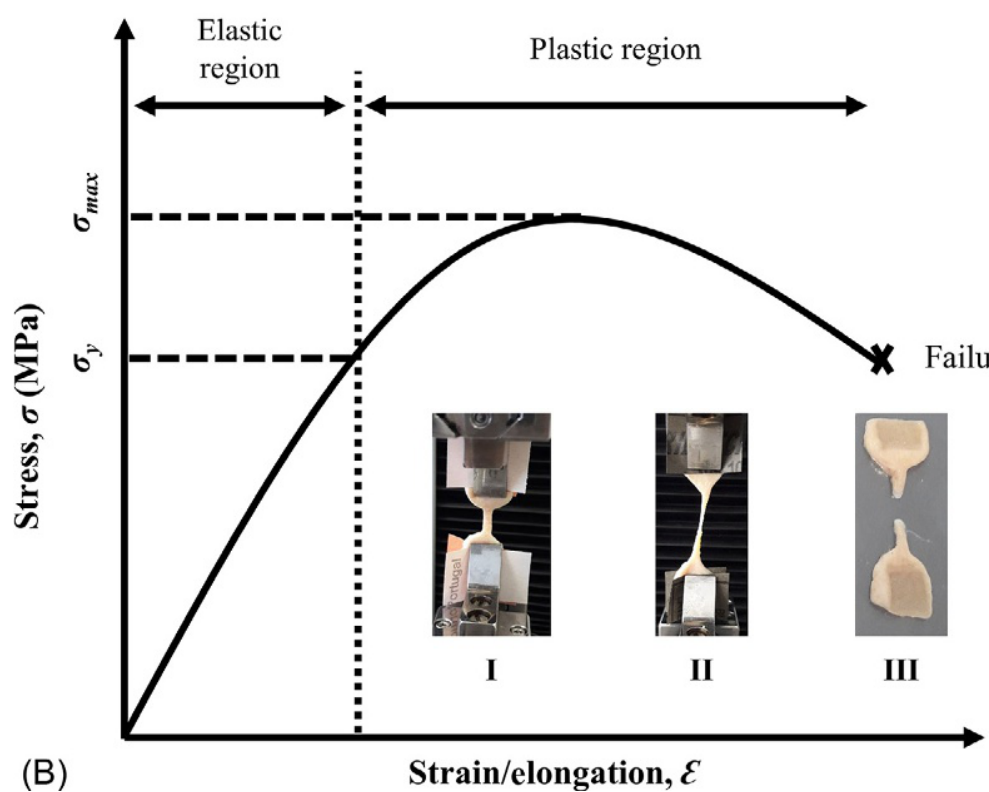

FIG. 17.4 Illustration of steps for mechanical tensile testing: (A) the samples are harvested and prepared into specific geometries; (B) typical stress-strain curve highlighting important measurement points. The typical stress-strain curve is characterized by an initial linear region before the yield point (called elastic region I) and a postyield nonlinear region (called plastic region II). In the elastic region, the loaded material will effectively return to its original length when the load is removed, that is, there is a negligible permanent extension. The slope of the stress-strain curve within the elastic region is defined by Hooke's law and Young's modulus can be determined. In the plastic region, the material begins to yield, which mean that the material does not recover to its original shape when the stress is removed. The yield point is called yield stress $\left(\sigma_{y}\right)$ and corresponds to the transition from linear (elastic region) to nonlinear behavior (plastic region). The maximum stress $\left(\sigma_{\max }\right)$ is the highest tensile stress that the material can support before failure, which means the ultimate tensile strength (UTS) of the material. At the end of the curve the specimen fractures (III).

fibers gradually elongate and tend to align toward the load application direction [4]. The alignment of the collagen fibers leads to a high resistance the load, which makes the skin tissue to behave as a stiffer material. Thus, the stress-strain relation turns linear due to the stretching and slippage of the collagen fibers $[53,54]$. The third stage begins after the yield point, for skin considered the strain above $60 \%-70 \%$. Then the ultimate tensile strength is reached, and the rupture of the fibers starts to occur due to the loss of fibrillar structure [55]. At this stage, skin tissue loses the capacity to return to its original shape upon removal of the tensile stress. 


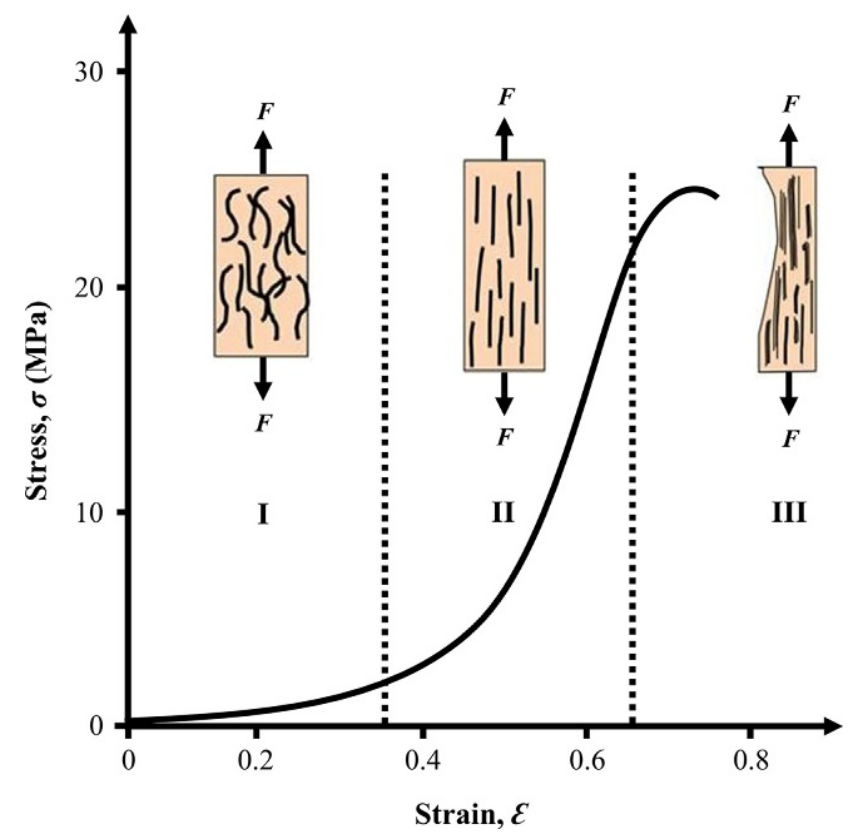

FIG. 17.5 General stress-strain curve for skin tissue under uniaxial tension and schematic drawings of the collagen fibers organization during the three stages of tensile loading: Stage I: the crimped collagen fibers begin to be oriented along the tensile axis, but its contribution can be neglected; Stage II: collagen fibers are straightening, and larger and larger amount of the fibrils reorient near to the tensile axis; Stage III: collagen fibers are fractured and curled back.

In the biaxial tests, loading is applied in two distinct directions. The first in vitro biaxial tension study of skin tissue was reported by Lanir and Fung [56]. They studied the biaxial mechanical properties of rabbit abdominal skin in two orthogonal directions. The results demonstrated the directional dependence of the stress-strain characteristics and the nonlinear response and the viscoelasticity of the skin. The comparison of the skin response under uniaxial and biaxial tension showed that the biaxial tensile loading results in the lateral compression of the stress-strain curve and the reduction in the strain before the entry into the linear region, which is due to the two-directional stretch of collagen fibers $[50,57]$. While also suitable to understand the two-directional properties of the skin, the biaxial methods are not appropriated to determine the failure point since the hooks affixed to the edges of the sample tend to tear the skin.

Overall, testing of whole skin indicates that resultant Young's modulus from tensile tests varies from 0.1 to 160.8 MPa, depending on the tests conditions, sample orientation, location, and so on (Table 17.1) [58-62].

\subsubsection{Compression Testing}

Although skin tissue is exposed to external compressive loads, the mechanical behavior of skin tissue under compression has been rarely studied. Shergold et al. [63] studied the uniaxial compressive response of pig back skin under a wide range of strain rates and showed that the stress-strain curves exhibit a similar profile to those obtained under the same conditions in tensile tests. Accordingly, the only difference is the strain levels at the transition to the different stages; the transitions in the compression tests occur at highest strain levels. Nonetheless, different studies confirmed that skin under compression is highly viscoelastic and shows a nonlinear and time-dependent mechanical behavior [63-66].

From our knowledge, the mechanical properties of human skin tissue under compression loadings are not clearly established yet. The few studies found in the literature are related to the animal skin.

\subsubsection{Indentation Testing}

Tensile and compression tests provide an important comprehension of the mechanical behavior of the skin in response to extreme loading conditions but fail in providing any insight into the skin microenvironment. Micro- or nanoscale techniques such as indentation tests using atomic force microscopy (AFM) have proved useful to examine the skin mechanical properties at small length scales [60, 67-69]. The test consists in the use of a rigid cylindrical, pyramidal, or spherical indenter tip, to apply a perpendicular force on a target area of the skin tissue corresponding to a specific cell location (Fig. 17.6). The indenter tip is attached to a flexible microcantilever, which bends toward or away from the skin sample when attractive or repulsive forces are present, respectively [70, 71]. During the measurements, topographical images and the vertical displacement of the cantilever and its deflection are simultaneously recorded 
TABLE 17.1 Young's Modulus of Human Skin Determined With Different Mechanical Tests

\begin{tabular}{|c|c|c|c|}
\hline Mechanical test & Skin location & Young's modulus, $E$ (MPa) & Reference \\
\hline \multirow[t]{10}{*}{ Uniaxial tensile (ex vivo) } & Abdomen & 14.96 & {$[78]$} \\
\hline & \multirow[t]{3}{*}{ Back (SC/E/D) } & 160.8 (parallel to the $\mathrm{Ll}$ ) & \multirow[t]{3}{*}[62]{} \\
\hline & & $121\left(45^{\circ}\right.$ to the $\left.\mathrm{Ll}\right)$ & \\
\hline & & $70.6\left(90^{\circ}\right.$ to the $\left.\mathrm{Ll}\right)$ & \\
\hline & \multirow[t]{2}{*}{ Back (SC/E/D) } & 112.47 (parallel to the $\mathrm{Ll}$ ) & \multirow[t]{2}{*}[10]{} \\
\hline & & 63.75 (90 to the $\mathrm{Ll}$ ) & \\
\hline & Forehead (E/D) & 0.33 & \multirow[t]{3}{*}[79]{} \\
\hline & Forearm (E/D) & 1.03 & \\
\hline & Submandibular neck (E/D) & 1.28 & \\
\hline & Scalp & 22.74 & {$[80]$} \\
\hline Uniaxial tensile (in vivo) & Leg/hand & $4.6-20$ & {$[81,82]$} \\
\hline \multirow[t]{8}{*}{ Indentation (ex vivo) } & Abdominal (SC/E) & $1-2$ & {$[60]$} \\
\hline & Abdominal (Dp) & $0.1-0.25$ & {$[83]$} \\
\hline & \multicolumn{3}{|l|}{ Breast (Dp) } \\
\hline & \multicolumn{3}{|l|}{ Gluteus (Dp) } \\
\hline & - & $0.0258-1.18$ & {$[74]$} \\
\hline & Forearm & 0.014 & {$[84]$} \\
\hline & Lower limb & $0.01-0.09$ & [85] \\
\hline & Forefoot plantar & $0.03-0.08$ & {$[86]$} \\
\hline \multirow[t]{3}{*}{ Indentation (in vivo) } & Forearm & $0.0045-0.008$ & {$[45]$} \\
\hline & Forearm & 0.0285 & {$[87]$} \\
\hline & Forearm & 0.0011 & {$[88]$} \\
\hline \multirow[t]{3}{*}{ Suction (in vivo) } & Forearm & $18-57$ & [89] \\
\hline & Forearm & $0.11-0.12$ & {$[90]$} \\
\hline & Forehead & $0.21-0.25$ & [90] \\
\hline
\end{tabular}

$S C$, stratum corneum; $E$, epidermis; $D$, dermis; $D p$, papillary dermis; $L l$, Langer lines.

and then converted to load-displacement curves [72]. For this equipment, both load and penetration depth can be controlled during the test.

From the AFM indentation measurements, the obtained values for human skin Young's modulus vary from $0.77 \mathrm{kPa}$ to $322 \mathrm{kPa}$ for dermal tissue, and some studies reported higher elastic modulus values in the mega Pascal range, potentially influenced by the collagen fibers in the probed area (Table 17.1) [61,73,74]. In fact, the contribution of the orientation of the collagen fibers to Young's modulus of the skin dermis and scar tissue was demonstrated by Grant et al. [74]. AFM imaging showed that the scarred skin has a higher degree of orientation of its collagen fibrils and displays stiffer behavior than the healthy intact skin and weaker viscoelastic creep and capability to dissipate energy at physiologically relevant frequencies.

\subsubsection{Suction Testing}

Suction test is one of the most widely used and accepted means of measurement of skin mechanical properties in vivo. Under this test, the tissue is elevated by applying a partial vacuum using a circular aperture, and the skin deformation is quantified by optical or ultrasound devices [75]. Generally, the obtained results only take into account the negative pressure applied, that is, suction, and the elevation of the dome of skin drawn up to deduce the properties of the skin. The suction device is used to measure the skin distensibility and the in vivo mechanical properties by measuring the skin elasticity as a percentage of skin retraction after the stretch [76]. This method has as a major disadvantage: the dependence on the experimental conditions used such as the size of the suction cup and the negative pressure 

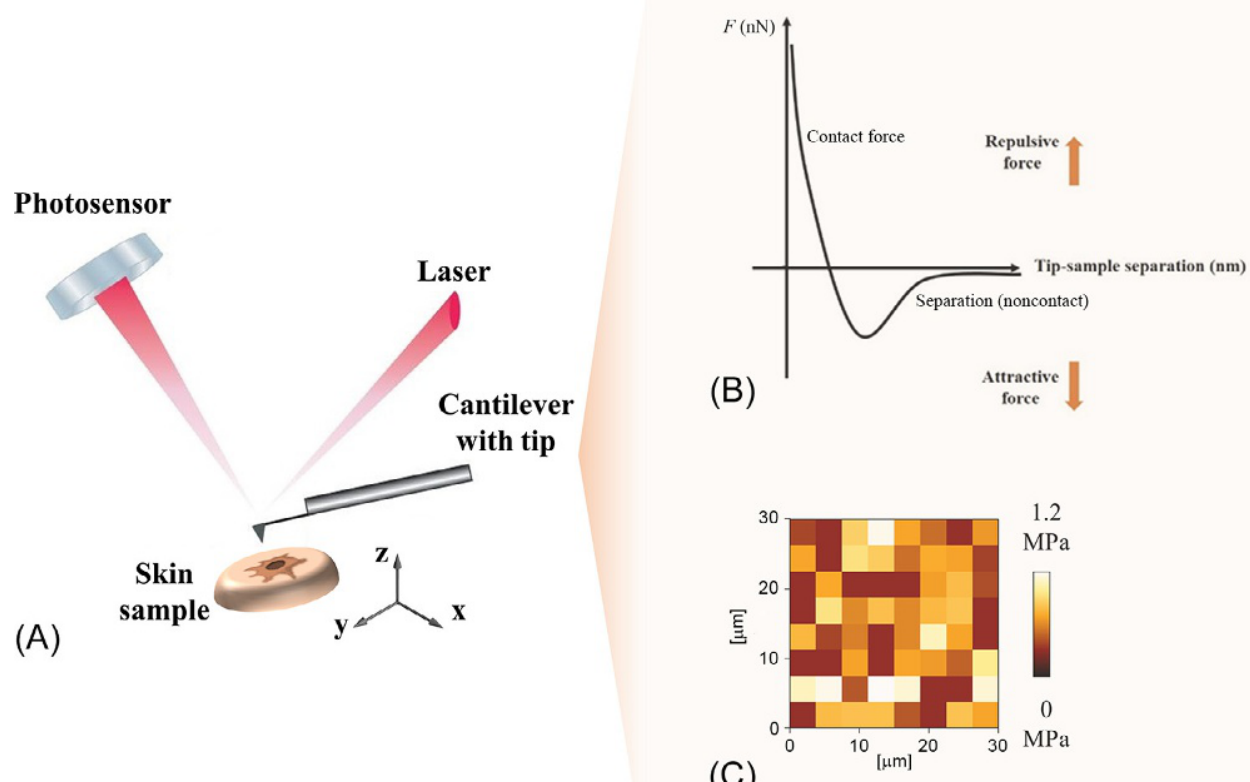

FIG. 17.6 Illustration of indentation test in and representative result plotting. (A) Bio-AFM setup in which skin sample is indented with the AFM tip with well-defined geometry; (B) sketch force-distance curve during force mapping; (C) AFM Young's modulus distribution in the analyzed skin area.

applied. Several authors have used this approach to calculate the mechanical properties of human skin $[9,58,76,77]$. Young's Modulus measured by suction tests varies from 0.1 to $57 \mathrm{MPa}$ (Table 17.1).

\subsection{SKIN MECHANOBIOLOGY}

\subsubsection{Mechanosensing and Mechanotransduction}

The field of mechanobiology studies the response of tissues and cells to mechanical signals that can be given by their surrounding environment [91]. Tissues and cells are continuously exposed to forces $(F)$ of different types (compression, tension, and shear) and of varying magnitude, direction, and frequency that are able to change tissue/cell behaviors [92]. For instance, skin is continuously exposed to tension and compression forces resulting from ordinary daily actions like stretching. Mechanical forces also exist at the cellular level due to the tension forces of neighboring cells and/or surrounding ECM and contractile forces of cell cytoskeleton [92] (Fig. 17.7). Tissues and cells are able to sense those forces by the process of mechanosensing and convert this signal into a biological response through a process of mechanotransduction [91]. The process of mechanosensing is mediated by force-induced changes in the conformation of a protein, exposure of a peptide sequence of a protein, opening of ion channels, or receptor-ligand binding changes [93]. Integrins are the well-known transmembrane mechanoreceptors related with cell adhesion to the ECM, whereas cadherins, occludins, and connexins are the mechanoreceptors responsible for cell-cell mechanosensing [93, 94]. Other mechanoreceptors include G-protein-coupled receptors (GPCR, e.g., chemokine receptors (CXCR)), enzyme-like receptors (e.g., Discoidin domain receptors (DDR), ephrin receptors, and platelet endothelial cell adhesion molecule 1 (PECAM) receptors), ion channels (e.g., transient receptor potential (TRP) channels), lipid rafts, and glycocalyx [95].

FIG. 17.7 Cells are in a state defined as contractile tension due to the traction and tension forces applied to the cells. In equilibrium, tension and traction forces are in balance, and cell mechanotransduction is not activated. Mechanotransduction is activated once the forces are unbalanced. Cell cytoskeletons elongate once ECM-cell tension forces are higher than cell cytoskeleton contraction forces, whereas the cytoskeleton relaxes once cell cytoskeleton contraction forces are higher than ECM-cell tension forces.

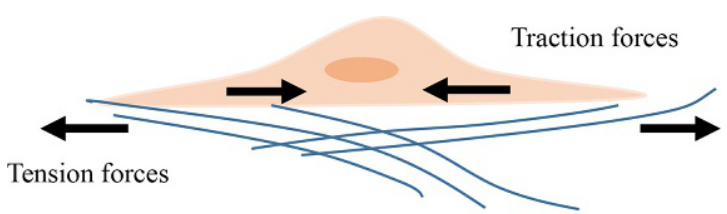

CONTRACTILE TENSION 
Mechanosensing is then followed by the process of mechanotransduction that occurs through alterations at the subcellular and molecular levels through intracellular proteins (e.g., vinculin and talin), kinases and phosphatases (e.g., focal adhesion kinase (FAK)), cytoskeletal components (i.e., actin filament and microtubule), or intermediate filaments (e.g., keratin, dermin, plectin, lamin, and vimentin) [93]. Thus it is clear why the mechanosensing force is mechanotransduced into a biological response related with the activated signaling pathway that can be, for instance, adhesion, survival, apoptosis, proliferation, migration, or differentiation [93, 96, 97].

The effect of the stiffness and topography over skin cells has been largely reviewed, but the result of mechanical forces on skin cells has only been considered recently and will be the focus of this section. In the skin, different cells are able to mechanosense mechanical forces. The most distinctive mechanoreceptors are neurons that are able to sense touch, itch, pain, and temperature stimuli. Merkel cells, the Ruffini corpuscle, and the Meissner's corpuscle both at the epidermis and dermis of the skin are also able to mechanosense external forces and transmit the signal to sensory neurons called low-threshold mechanoreceptors (LTMRs) that in turn send the signal to the central nervous system [98, 99]. Other cells existing in the skin, including endothelial cells [100], adipocytes [101], stem cells [102], Langerhans cells [103], and melanocytes [104, 105], also sense mechanical stimuli, but the effect of mechanical loading over skin cells has only been explored for the main skin resident cells-fibroblasts and keratinocytes. This is probably because these cells, in addition to the external stimuli, are continuously exposed to internal passive tension forces resulting from cell-cell (keratinocytes and fibroblasts) and cell (fibroblast)-ECM interactions. External forces exerted at air-epidermis interface enhance the active tension in the skin and on both cell types due to the stretching of cell junctions and collagen fibrils. The mechanical stimuli are transmitted along the air-epidermis interface throughout the epidermis due to hemidesmosomes existing in the epidermal-dermal junction that maintain the mechanical continuity along the two skin layers [106]. Animal models have been used to understand the effect of forces over the different skin cells [25-27]. However, these studies are mainly performed using rodent skin that is both anatomically and mechanically different from human skin [107]. Moreover, human skin is a complex organ, and the continuous exposition to different stimuli, including other than mechanical ones such as chemical, radiation, electric, etc., renders difficult the understanding of isolated effects. Hence, the effect of external forces over keratinocytes and fibroblasts has been mainly explored in vitro by the application of external forces onto cells.

\subsubsection{Effect of Forces Over Fibroblasts and Keratinocytes}

The first study of the effect of forces over skin cells was in 1990. Görmar et al. showed that cyclic compression forces of pestle-shaped weights over keratinocytes induced their differentiation [108]. Similar studies using compression forces conducted in dermal skin fibroblasts showed increased production of metalloproteinases (MMPs) in response to the stimulus [109]. To our knowledge, these were the only studies that explored the effect of compression forces over skin cells. This may be due to the limited significance of compression forces, as keratinocytes and fibroblasts in the skin are only subjected to tension forces. Thus skin mechanobiology studies have focused on the effect of tension forces of different orientations, magnitudes, frequencies, and periods over keratinocytes (Table 17.2) and fibroblasts (Tables 17.3 and 17.4).

In the late 90's, researchers started developing in-house mechanical loading units to study the effect of tension on cells cultured onto silicone substrates [110,111]. Keratinocyte mechanobiology was empowered with the arising of mechanical stretching units for sell [16, 112-115]. Tension forces showed to affect keratinocytes by activating the epithelial-mesenchymal transition [115], promoting proliferation [112, 113, 115-118] through the activation of ERK signaling pathway [111, 116, 119], and by activating antiapoptotic mechanisms [120,121] mediated by the activation of the Akt signaling pathway [117, 120, 121]. Moreover, tension forces induced keratinocytes migration [122, 123], basement membrane ECM production [16, 118], expression of basal layer-associated keratins [16, 116], and decreased expression of upper layer-associated ones [116]. These responses seem to be mediated by integrin $\beta 1[111,119,123]$. These studies revealed that tension mechanical loading has a prominent effect on keratinocytes and that the observed responses are independent of force orientation, magnitude, frequency, and period of the loading (Fig. 17.8).

The first observations regarding the mechanobiology of fibroblasts refer to 1983 when Allen and Schor detected the contraction of free-floating collagen gels loaded with dermal fibroblasts [127, 128]. In the absence of gel anchorage (no mechanical loading), the contractile tension existing between dermal fibroblasts and collagen gels becomes unbalanced prevailing fibroblasts traction forces that lead to gel contraction. This did not occur if gels were anchored because the mechanical loading due to anchoring maintained a balanced between the cell traction and the cellECM forces [127] (Fig. 17.9). The dermal fibroblasts in the anchored gels showed an elongated morphology and produced higher amounts of ECM in contrast with the round morphology and the reduced synthesis of the mediators of ECM synthesis observed with fibroblasts in free-floating gels [127, 129-131] (Fig. 17.9, Table 17.3). These responses 
TABLE 17.2 Mechanotransduced Response of Keratinocytes Subjected to Tension Loading

\begin{tabular}{|c|c|c|c|c|}
\hline Force & Substrate & Cell & Mechanotransduced response & Reference \\
\hline $\begin{array}{l}\text { Uniaxial } \\
\text { Cyclic } \\
\text { Strain: } 14 \%-33 \%\end{array}$ & $\mathrm{~N} / \mathrm{A}$ & $\mathrm{KCs}$ & $\begin{array}{l}\uparrow \mathrm{IL}-1 \alpha \\
\uparrow \mathrm{IL}-1 \mathrm{R} \text { antagonist } \\
\uparrow E \text {-selectin in human vascular endothelial cells mediated by media } \\
\text { conditioned by mechanically stimulated KCs } \\
\text { Activate vascular endothelium }\end{array}$ & [110] \\
\hline $\begin{array}{l}\text { Uniaxial } \\
\text { Static/cyclic } \\
\text { Strain: } 10 \% \\
\text { Frequency: } 0.17 \mathrm{~Hz} \\
\text { Period: } 15 \mathrm{~min}-7 \text { days }\end{array}$ & Type I collagen & hNFKCs & $\begin{array}{l}\uparrow \text { Proliferation } \uparrow \text { DNA synthesis } \uparrow \text { Elongation } \uparrow \text { Protein synthesis } \\
\downarrow \text { cAMP } \downarrow \text { PKA } \downarrow \text { PGE2 } \\
\text { Regulated by Il- } 1 \text { release }\end{array}$ & {$[112,113]$} \\
\hline $\begin{array}{l}\text { Uniaxial } \\
\text { Static } \\
\text { Strain: } 10 \% \\
\text { Period: } 5 \mathrm{~min}-24 \mathrm{~h}\end{array}$ & Arginine & $\mathrm{HaCaT}$ & $\begin{array}{l}\text { Activation of ERK signaling pathway } \\
\text { Regulated by } \beta 1 \text {-integrins }\end{array}$ & [111] \\
\hline $\begin{array}{l}\text { Uniaxial } \\
\text { Static } \\
\text { Strain: } 20 \% \\
\text { Period: } 24 \mathrm{~h}\end{array}$ & Type I collagen & NHK & $\begin{array}{l}\uparrow \text { Calcium influx } \\
\uparrow \text { Proliferation } \\
\text { Activation of ERK } 1 / 2 \text { and Akt signaling pathways } \\
\uparrow \mathrm{K} 6 \downarrow \mathrm{K} 10\end{array}$ & [116] \\
\hline $\begin{array}{l}\text { Uniaxial } \\
\text { Static } \\
\text { Strain: } 10 \% \\
\text { Period: } 5 \mathrm{~min}\end{array}$ & Arginine & $\mathrm{HaCaT}$ & $\begin{array}{l}\text { Regulated by angiotensin II type } 1 \text { receptor. } \\
\text { Activation of Akt signaling pathway } \\
\text { Antiapoptotic }\end{array}$ & [121] \\
\hline $\begin{array}{l}\text { Uniaxial } \\
\text { Static } \\
\text { Strain: } 20 \% \\
\text { Period: } 15-30 \mathrm{~min}\end{array}$ & Type I collagen & NHK & $\begin{array}{l}\text { Activation of Akt signaling pathway } \\
\text { Antiapoptotic }\end{array}$ & [120] \\
\hline $\begin{array}{l}\text { Uniaxial } \\
\text { Static } \\
\text { Strain: } 10 \% \\
\text { Period: } 5 \mathrm{~min}-48 \mathrm{~h}\end{array}$ & $\begin{array}{l}\text { Type IV collagen, fibronectin, laminin, } \\
\text { arginine, fetal calf serum }\end{array}$ & $\mathrm{HaCaT}$ & $\begin{array}{l}\uparrow \text { Substrate adhesion to fibronectin and collagen type IV but not to laminin } \\
\text { Activation of ERK signaling pathway } \\
\text { Regulated by } \beta 1 \text {-integrins }\end{array}$ & [119] \\
\hline $\begin{array}{l}\text { Uniaxial } \\
\text { Static/cyclic } \\
\text { Strain: } 10 \%-30 \% \\
\text { Frequency: } 1 \mathrm{~Hz} \\
\text { Period: } 3 \text { min- } 24 \mathrm{~h}\end{array}$ & Type I/IV collagen & NHKs & $\begin{array}{l}\downarrow \text { uPA protease (static stretch) } \\
\uparrow \text { uPA protease (cyclic stretch) }\end{array}$ & [114] \\
\hline $\begin{array}{l}\text { Uniaxial } \\
\text { Static/cyclic } \\
\text { Strain: } 10 \% \\
\text { Frequency: } 0.17 \mathrm{~Hz} \\
\text { Period: } 72 \mathrm{~h}\end{array}$ & Type I collagen & $\mathrm{HaCaT}$ & $\begin{array}{l}\text { Orientation perpendicular to stress } \\
\text { Reduced area } \\
\uparrow \text { MMP-9 protease }\end{array}$ & [124] \\
\hline
\end{tabular}


+ relaxation)

$\downarrow$ Proliferation (after 2 days of I)

Strain: 10\%

Frequency: $0.17 \mathrm{~Hz}$

Uniaxial

Cyclic

Strain: 10\%-20\%

Frequency: $1 \mathrm{~Hz}$

Period: $24-48 \mathrm{~h}$

Uniaxial

Static

in: $15 \%-30 \%$

Period: 6 days

Uniaxial

Cyclic

Type I collagen

HaCaT hESCs

$\uparrow$ E-cadherin, catenin $\beta 1$, connexin 43 , desmoglein 1 , endothelin 1, integrin $\alpha 6$, IL- $\alpha 1$, keratin [16] $1 / 6 / 10 / 14$, KGFR, laminin $\alpha 5$, fibronectin 11, MMP-9

Frequency: $0.2 \mathrm{~Hz}$

Period: 12

Uniaxial

Cyclic

Strain: $10 \%$

Frequency: $0.5 \mathrm{~Hz}$

Period: $1-72 \mathrm{~h}$

Uniaxial

Cyclic

Strain: $10 \%$

Frequency: $0.03 \mathrm{~Hz}$

Period: 5 days

Uniaxial

Static

Strain: $20 \%$

Period: 6 days

Uniaxial

Static

Strain: $10 \%$

Period: $5 \mathrm{~min}$

Uniaxial

Static/cyclic

Strain: $20 \%$

Frequency: $1 \mathrm{~Hz}$

Period: 6 days

Type I collagen

Type I collagen

Arginine

Type I collagen or fibronectin
Thicker epidermal layer

HSE

$(\mathrm{NHK}+\mathrm{HF})$

$\uparrow$ Laminin 5

$\uparrow$ Collagen IV/VII

Development of basement membrane

HaCaT $\quad$ KC migration mediated by $\beta 1$-integrin

$\mathrm{HF}$

$\mathrm{HaCaT}$

Desmosomes and keratins involved in mechanosensing

$\downarrow$ Proliferation (cyclic)

Regulated by $\beta 1$-CASK signal pathway

$B A D$, BCL2-antagonist of cell death; $c A M P$, cyclic adenosine monophosphate; $E G F$, epidermal growth factor; $E R K s$, extracellular signal-regulated kinases; $H a C a T$, keratinocyte cell line from human adult skin; $h E S C s$, keratinocytes derived from human embryonic stem cells; $H F$, (primary) human fibroblasts; $h N F K C$ s, human neonatal foreskin keratinocytes; $H S E$, human skin equivalents; $I L$, interleukin; KCs, keratinocytes; $K G F R$, keratinocyte growth factor receptor; $M M P$, metalloproteinase; $N / A$, not available; $N F-\kappa B$, nuclear factor kappa-light-chain enhancer of activated B cells; $N H K s$, (primary) normal human keratinocytes; $P D M S$, poly-dimethylsiloxane; $P G E 2$, prostaglandin E2; $P K A$, protein kinase $\mathrm{A} ; P K B$, proto-oncogene protein kinase $\mathrm{B}$; $T G F$, transforming growth factor; $u P A$, urokinase-type plasminogen activator. 
TABLE 17.3 Mechanotransduced Response of Human Dermal Fibroblasts Loaded into Free-Floating or Anchorage Type I Collagen Gels

\begin{tabular}{lll}
\hline Cell & Mechanotransduced response & Reference \\
\hline HNFFbs & $\begin{array}{l}\text { Cell migration } \\
\text { Gel contraction }\end{array}$ & {$[127]$} \\
HDFbs & $\downarrow$ Procollagen type I and III & {$[129]$} \\
& $\downarrow$ Carboxy-procollagen peptidases & \\
& $\downarrow$ Lysyl oxidase & \\
& (relaxation) & \\
HDFbs & $\downarrow$ Contractile forces $\downarrow$ Stress fibers $\downarrow$ Collagen contraction, \\
(fetal) & $\begin{array}{l}\text { modulated by PGE2 through cAMP-dependent mechanism } \\
\text { through the EP2 receptor (tension) }\end{array}$ & \\
HDFbs & $\downarrow$ hDFb size & {$[131]$} \\
& $\downarrow$ Mechanical force & \\
& $\downarrow$ TGF- $\beta 2$ receptor & \\
& $\downarrow$ SMAD3 pathway & \\
& $\downarrow$ ECM production & \\
& $($ relaxation) & \\
HDFbs & $\uparrow$ p130Cas & \\
& Phosphorylation of Src family kinase & \\
\hline
\end{tabular}

$h N F F b s$, human neonatal foreskin fibroblasts; $h D F b s$, human dermal fibroblasts; PGE, protaglandin E synthase; $c A M P$, cyclic adenosine monophosphate; $E P$, prostaglandin E receptor; $T G F$, transforming growth factor; ECM, extracellular matrix.

were then associated with the activation of the p130Cas phosphorylation of Src family kinase [132], of the PGE2 through cAMP-dependent mechanism in the EP2 receptor [130] and of the TGF- $\beta$ /SMAD3 pathway [131].

Further studies on human dermal fibroblasts were conducted by exposing the cells to tension forces (Table 17.4). The most evident result after the application of tensile forces on fibroblasts loaded in flexible silicon membranes was the increased production of ECM synthesis mediators [133] and of ECM proteins, especially collagen and elastin [17-24, 133-138]. Moreover, collagen fibrils [134, 136, 137, 139, 140] were aligned in agreement with the alignment of the cells but perpendicular to the stretch $[137,139-141]$. Interestingly, tension was also found to regulate levels of metalloproteinases (MMPs) and tissue inhibitors of metalloproteinases (TIMPs) secreted by fibroblasts, which impacts ECM degradation $[19,23,138,140,142,143]$. The secretion of some growth factors, including vascular endothelial growth factor (VEGF), TGF- $\beta 1$, TGF- $\beta 2$, TGF- $\beta 3$, connective tissue growth factor (CTGF), Cyr61, nerve growth factor (NGF), and stromal cell-derived factor (SDF)-1 $\alpha$ was also found to be upregulated after subjecting fibroblasts to tension forces [137, $138,144]$. Moreover, tension leads to increased cell migration [140] and proliferation [24, 137, 138] and reduce cell apoptosis $[18,140]$. All these results suggest that fibroblasts present a more active "synthetic" phenotype that coincides with myofibroblast phenotype as shown by the expression of $\alpha$-SMA $[19,135,145,146]$. These mechanotransduced responses are mediated by different signaling pathways and mediators, including integrin $\beta 1$ [24, 137, 141], focal adhesion kinase [141], Rho GTPases [141], TGF- $\beta$ pathway [24, 133, 135, 137, 147], p38 pathway [21, 135, 141, 148], ERK pathway [18, 21, 135, 148], Jnk pathway [18], Akt pathway [18, 148], Wnt pathway [140], SMAD [147], and P130cas [24, 137]. Nevertheless, in some studies, tension was found to decrease fibroblast proliferation [20, 148], collagen production [20,149], and the release of CTFG [149, 150].

\subsection{BIOMECHANICS AND MECHANOBIOLOGY IN THE CONTEXT OF SKIN WOUND HEALING}

Healthy skin tissue is normally under tensile stress, but upon a small incisional wound, the skin relaxes. Cell-cell and cell-matrix forces are disrupted at the wound margins breaking the cell stress-shielding cap. A wound of a greater diameter than the incision wound that tends to elongate in the direction of the greatest stress is formed. Wound elongation after a surgical incision was originally demonstrated by the 19th century by the German anatomist Karl Langer $[5,151]$. Langer thrust conical spikes through the skin of cadavers producing multiple splits over the entire human body and observed that the wound transformed into an elliptic form. By joining the major axes of these ellipses, he drew and catalogued the pattern of tension lines on the body, producing what we now term Langer's lines [5]. These 
TABLE 17.4 Mechanotransduced Response of Dermal Fibroblasts After Tension Loading

\begin{tabular}{|c|c|c|c|c|}
\hline Force & Substrate & Cell & Mechanotransduced response & Reference \\
\hline $\begin{array}{l}\text { Cyclic } \\
\text { Biaxial } \\
\text { Strain: } 20 \% \\
\text { Frequency: } 1 \mathrm{~Hz} \\
\text { Period: } 48 \mathrm{~h}\end{array}$ & Type I collagen & hDFbs & $\begin{array}{l}\uparrow \text { Procollagen } \\
\uparrow \text { Proteinase C } \\
\text { Activated by TGF- } \beta \text { - }\end{array}$ & [133] \\
\hline $\begin{array}{l}\text { Uniaxial } \\
\text { Force: } 120 \text { dynes } \\
\text { Cyclic } \\
\text { Strain: } 10 \% \\
\text { Frequency: } 11 \text { dynes } / \mathrm{min} \\
\text { Period: } 10 \mathrm{~min}-11 \mathrm{~h}\end{array}$ & $\begin{array}{l}\text { Collagen Lattices } \\
\text { Collagen Sponges }\end{array}$ & $\mathrm{hDFbs}$ & $\begin{array}{l}\uparrow \text { MMP- } 2, \text { MMP- } 9 \text {, and PLAT } \\
\downarrow \text { MMP- } 3 \text { and uPA }\end{array}$ & {$[142,143]$} \\
\hline $\begin{array}{l}\text { Equibiaxial cyclic } \\
\text { Strain: } 20 \% \\
\text { Frequency: } 0.1 \mathrm{~Hz} \\
\text { Period: } 24 \mathrm{~h}\end{array}$ & Type I collagen & hDFbs & $\begin{array}{l}\uparrow \text { Cell proliferation transcripts } \\
\uparrow \text { Connective tissue synthesis } \\
\downarrow \text { ECM degradation } \downarrow \text { Inflammatory } \\
\text { mediators } \\
\uparrow \text { VEGF, TGF- } \beta 1, \text { TGF- } \beta 3, \text { CTFG, Cyr } 61 \\
\text { transcripts }\end{array}$ & {$[138]$} \\
\hline $\begin{array}{l}\text { Uniaxial } \\
\mathrm{N} / \mathrm{a}\end{array}$ & $\begin{array}{l}\text { Rat tail } \\
\text { Type I collagen }\end{array}$ & $\begin{array}{l}\text { hDFbs } \\
\text { (healthy and striae) }\end{array}$ & $\begin{array}{l}\uparrow \alpha \text {-SMA } \\
\uparrow \text { Contractile force }\end{array}$ & [145] \\
\hline $\begin{array}{l}\text { Equibiaxial } \\
\text { Cyclic } \\
\text { Strain: } 16 \% \\
\text { Frequency: } \\
0.2 \mathrm{~Hz} \\
\text { Period:8 days }\end{array}$ & Fibrin & hDFbs & $\uparrow$ Stronger gels $\uparrow$ Denser $\uparrow$ Thinner $\uparrow$ Collagen & [17] \\
\hline $\begin{array}{l}\text { Cyclic } \\
\text { Strain: } 10-24 \% \\
\text { Frequency: } 0.1-0.17 \mathrm{~Hz} \\
\text { Period: } 24 \mathrm{~h}\end{array}$ & Type I collagen & hDFbs & $\begin{array}{l}\downarrow \text { Proliferation } \\
\text { Activation of } \mathrm{p} 38 \text { and ERK } 1 / 2 \text { (repetitive) } \\
\text { Activation of AKT and BAD pathways } \\
\text { (intermittent) }\end{array}$ & [148] \\
\hline $\begin{array}{l}\text { Uniaxial cyclic } \\
\text { Strain: } 20 \% \\
\text { Frequency: } 0.16 \mathrm{~Hz}\end{array}$ & Type I collagen & $\mathrm{hDFbs}$ & $\begin{array}{l}\downarrow \text { CTFG } \\
\downarrow \text { COL1A2 } \\
\uparrow \text { Heparan sulfate } \\
\text { proteoglycan } 2\end{array}$ & [149] \\
\hline $\mathrm{N} / \mathrm{a}$ & PGA fibers & hDFbs & $\begin{array}{l}\text { Spindle shape cells } \\
\text { Aligned collagen fibers } \\
\uparrow \text { Collagen fibril diameter } \\
\uparrow \text { Tensile strength }\end{array}$ & [134] \\
\hline $\begin{array}{l}\text { Axial } \\
\text { Cyclic } \\
\text { Strain: } 4-12 \% \\
\text { Frequency: } 0.1 \mathrm{~Hz} \\
\text { Period: } 30 \mathrm{~min}-12 \mathrm{~h}\end{array}$ & Type I collagen & hNFFbs & $\begin{array}{l}\text { Cell orientation } \\
\text { Activation of FAK, p38, and Rho } \\
\text { Regulated in part by integrin } \beta 1\end{array}$ & [141] \\
\hline $\begin{array}{l}\text { Uniaxial } \\
\text { Cyclic } \\
\text { Strain: } 10 \% \\
\text { Frequency: } 2 \mathrm{~mm} / \mathrm{min} \\
\text { Period: } 7 \mathrm{w}\end{array}$ & $\begin{array}{l}\text { Fibrin-based } \\
\text { tubular constructs }\end{array}$ & hNDFbs & $\begin{array}{l}\uparrow \text { Collagen } \uparrow \text { Elastin } \uparrow \text { ECM deposition and } \\
\text { disorganization } \\
\uparrow \alpha \text {-SMA and SMAD } 2 / 3 \\
\text { Activation of TGF- } \beta 1 \text { and p38 } \\
\text { Inhibition ERK }\end{array}$ & [135] \\
\hline $\begin{array}{l}\text { Biaxial } \\
\text { Cyclic } \\
\text { Strain: } 5 \% \\
\text { Frequency: } 0.3 \mathrm{~mm} / \mathrm{s} \\
\text { Period: } 60-90 \mathrm{~min}\end{array}$ & Fibrin gels & hDFbs & $\begin{array}{l}\text { Fiber alignment } \\
\text { Fibrin degradation } \\
\uparrow \text { Elastin and collagen, in a geometry- } \\
\text { dependent manner }\end{array}$ & [136] \\
\hline $\begin{array}{l}\text { Equibiaxial } \\
\text { Cyclic } \\
\text { Strain: } 15 \% \\
\text { Frequency: } 0.1 \mathrm{~Hz} \\
\text { Period: } 24 \mathrm{~h}\end{array}$ & Type I Collagen & hDFbs & $\begin{array}{l}\downarrow \alpha \text {-SMA, CTGF, and ET- } 1 \\
\alpha \text {-SMA and CTGF modulated by ET- } 1 \text { levels }\end{array}$ & [150] \\
\hline
\end{tabular}


TABLE 17.4 Mechanotransduced Response of Dermal Fibroblasts After Tension Loading—cont'd

\begin{tabular}{|c|c|c|c|c|}
\hline Force & Substrate & Cell & Mechanotransduced response & Reference \\
\hline $\begin{array}{l}\text { Uniaxial } \\
\text { Cyclic } \\
\text { Strain: } 10 \% \\
\text { Frequency: } 0.5 \mathrm{~Hz} \\
\text { Period: } 1 \mathrm{~h}\end{array}$ & $\mathrm{~N} / \mathrm{A}$ & hDFbs & $\uparrow N G F$ and TGF- $\beta 2$ & [144] \\
\hline $\begin{array}{l}\text { Uniaxial } \\
\text { Cyclic } \\
\text { Strain: } 120 \% \\
\text { Frequency: } 0.17 \mathrm{~Hz} \\
\text { Period: } 24 \mathrm{~h}\end{array}$ & $\mathrm{~N} / \mathrm{A}$ & hDFbs & $\begin{array}{l}\uparrow \text { Migration } \\
\text { Cell orientation } \\
\downarrow \text { Apoptosis } \\
\uparrow \text { Collagen degradation } \\
\text { Regulated by Wnt and integrin }\end{array}$ & [140] \\
\hline $\begin{array}{l}\text { Uniaxial } \\
\text { Static/cyclic } \\
\text { Strain: } 5 \% \\
\text { Frequency: } 0.5 \mathrm{~Hz} \\
\text { Period: } 3-4 \mathrm{w}\end{array}$ & Tubular cell sheets & $\mathrm{hNDFbs}$ & $\begin{array}{l}\text { Cell and collagen alignment } \\
\uparrow \text { Stiffness }\end{array}$ & [139] \\
\hline $\begin{array}{l}\text { Cyclic/static } \\
\text { Uniaxial } \\
\text { Strain: } 10 \% \\
\text { Frequency: } 1 \mathrm{~Hz} \\
\text { Period: } 96 \mathrm{~h}\end{array}$ & Type I collagen & hDFbs & $\begin{array}{l}\uparrow \text { Type I procollagen } \\
\uparrow \text { TIMP- } 1 \\
\downarrow \text { MMP- } 1 \\
\text { Differentiation }\end{array}$ & [19] \\
\hline $\begin{array}{l}\text { Cyclic } \\
\text { Frequency: } 1 \mathrm{~Hz}\end{array}$ & Type I collagen & hDFbs & $\begin{array}{l}\downarrow \text { Apoptosis } \\
\uparrow \text { Cell survival } \\
\uparrow \text { Adhesion } \\
\uparrow \text { ERK } \uparrow \text { JNKs } \uparrow \text { AKT } \\
\uparrow \text { Synthesis ECM } \\
\uparrow \text { Denser focal adhesion } \\
\uparrow \text { VEGF } \uparrow \text { SDF- } 1 \alpha\end{array}$ & {$[18]$} \\
\hline $\begin{array}{l}\text { Uniaxial } \\
\text { Cyclic } \\
\text { Strain: } 10 \% \\
\text { Frequency: } 0.1 \mathrm{~Hz} \\
\text { Period: } 48 \mathrm{~h}\end{array}$ & $\mathrm{~N} / \mathrm{A}$ & $\begin{array}{l}\text { hDFbs (from two different } \\
\text { skin sites) }\end{array}$ & $\begin{array}{l}\uparrow \text { Proliferation } \\
\uparrow \text { Integrin } \beta 1 \text {, p130Cas, and TGF- } \beta 1\end{array}$ & {$[24]$} \\
\hline $\begin{array}{l}\text { Uniaxial } \\
\text { Static } \\
\text { Strain: } 10 \% \\
\text { Period: } 24 \mathrm{~h}\end{array}$ & $\begin{array}{l}\text { Rat tail } \\
\text { Type I collagen }\end{array}$ & $\begin{array}{l}\text { hDFbs } \\
\text { hNFFbs }\end{array}$ & $\begin{array}{l}\uparrow \text { MMP-2, TIMP-2, and collagen type III } \\
\text { in HDFs (hDFbs but not hNFFbs) }\end{array}$ & {$[23]$} \\
\hline $\begin{array}{l}\text { Static/cyclic } \\
\text { Strain: } 20 \mathrm{~Hz} \\
\text { Frequency: } 1 \mathrm{~Hz} \\
\text { Period: } 6 \mathrm{~d}\end{array}$ & $\mathrm{~N} / \mathrm{A}$ & hDFbs & $\begin{array}{l}\downarrow \text { Proliferation (cyclic) } \\
\downarrow \text { Collagen I (cyclic) } \\
\uparrow \text { Fibronectin (cyclic) } \\
\uparrow \text { Collagen I (static) } \\
\downarrow \text { Fibronectin (static) }\end{array}$ & {$[20]$} \\
\hline $\begin{array}{l}\text { Uniaxial } \\
\text { Cyclic } \\
\text { Strain: } 10 \%-20 \% \\
\text { Frequency: } 0.1 \mathrm{~Hz} \\
\text { Period: } 24 \mathrm{~h}\end{array}$ & $\mathrm{~N} / \mathrm{A}$ & $\begin{array}{l}\text { hDFbs (hypertrophic and } \\
\text { normal skin) }\end{array}$ & $\begin{array}{l}\uparrow \text { Cell proliferation } \\
\text { Cell Orientation } \\
\uparrow \text { TGF- } \beta 1 \\
\uparrow \text { Collagen } \\
\text { Regulated by integrin } \beta 1 \text { and P130Cas }\end{array}$ & [137] \\
\hline $\begin{array}{l}\text { Uniaxial } \\
\text { Cyclic } \\
\text { Strain: } 15 \% \\
\text { Frequency: } 0.5 \mathrm{~Hz} \\
\text { Period: } 15 \mathrm{~min}-2 \text { weeks }\end{array}$ & Fibrin gels & hDFbs & $\begin{array}{l}\uparrow \text { Collagen deposition } \\
\text { Activation of ERK } 1 / 2 \text { and p38 }\end{array}$ & {$[21]$} \\
\hline
\end{tabular}

$C T F G$, connective tissue growth factor; $E C M$, extracellular matrix; $E R K$, extracellular signal-regulated kinases; $E T-1$, endothelin 1; FAK, focal adhesion kinase; $h D F b s$, human dermal fibroblasts; $h N D F b s$, human neonatal dermal fibroblasts; $h N F F b s$, human neonatal foreskin fibroblasts; JNK, c-Jun N-terminal kinase; $M M P$, metalloproteinase; N/A, not available; NGF, nerve growth factor; $P L A T$, plasminogen activator; SDF-1, stromal cell-derived factor 1; TGF, transforming growth factor; TIMP, metalloproteinase inhibitor; $u P A$, urokinase-type plasminogen activator; $V E G F$, vascular endothelial growth factor; $\alpha$-SMA, $\alpha$ smooth muscle actin. 

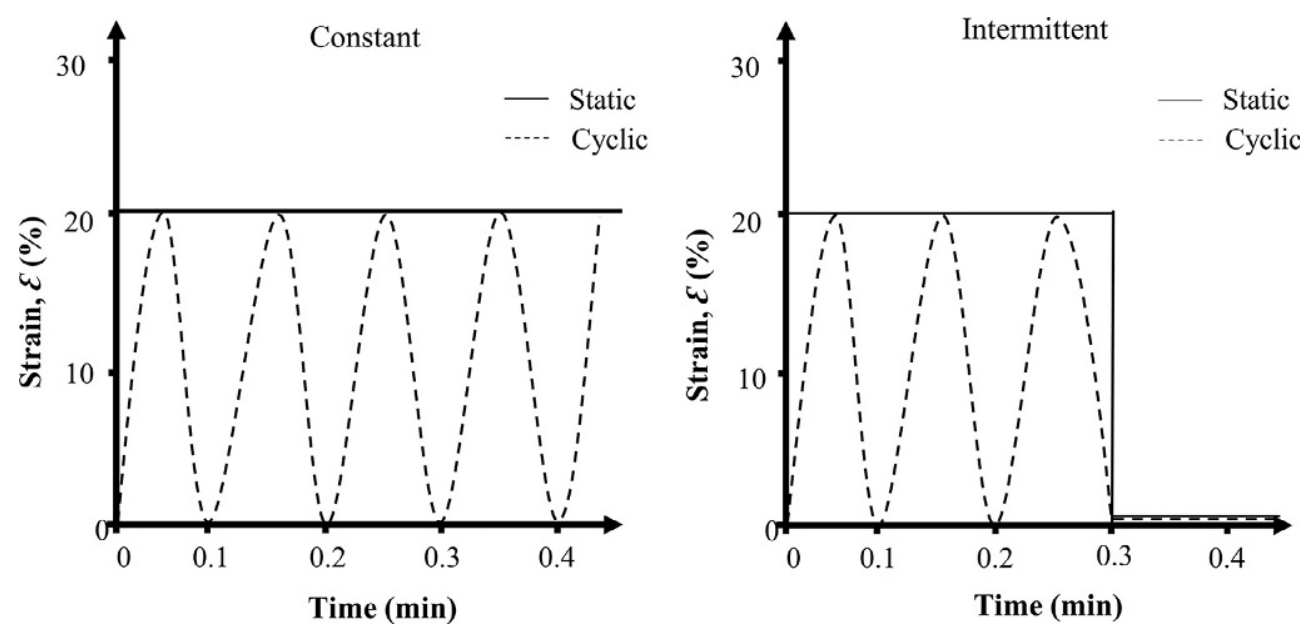

FIG. 17.8 Tension forces applied into cells.
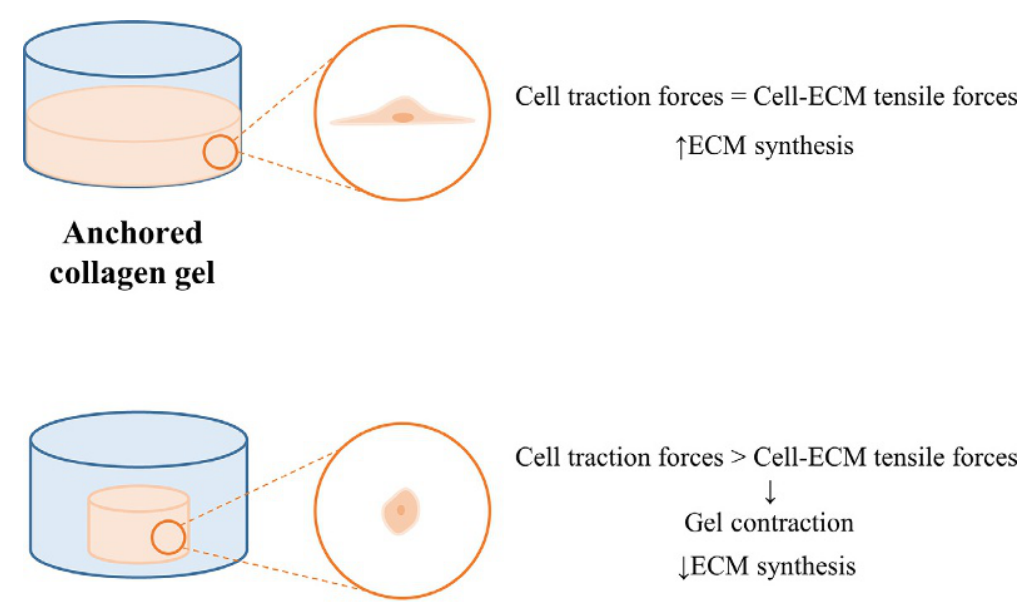

\section{Free-floating} collagen gel

FIG. 17.9 Mechanotransduced response of human dermal fibroblasts loaded into free-floating or anchorage type I collagen gels.

lines run parallel to the main collagen fibers in the dermis but do not always follow the line of wrinkle [10]. Through these studies, it was possible to demonstrate the anisotropic nature of skin and to map the natural lines of great tension that occur within the skin tissue. Hence, surgical incisions that are performed perpendicular to the lines tend to pull open in the direction of the greatest stress and close with the formation of a scar tissue [152]. This evidence was further confirmed in a pig model that holds more significance in terms of skin anatomy and biomechanics [28, 153]. This has motivated prevention actions during surgical procedures to reduce scarring, that is, incision procedures are now being performed along the Langer's lines to reduce the scar area. Moreover, to prevent scar formation during the healing of incisional wounds, care products that relieve wound tension have emerged. Silicone bandages that contract the wound holding the incision margins together and bandages with zip that are able to distribute the forces during the skin closure through the action of a zip system are some examples. These bandages compress the wound along axial incision extension, and the magnitude of the force can be controlled, resulting in a reduced scar area. These therapeutic approaches are however inefficient in the treatment of excisional wounds as wound margins cannot be connected due to the lack of skin tissue. The healing of excisional wounds is associated with scarring due to the contraction of the dermis mediated by myofibroblasts. Myofibroblasts are specialized contractile fibroblasts differentiated from fibroblasts in response to transforming growth factor $\beta 1$ (TGF- $\beta 1$ ) [11]. Myofibroblasts express $\alpha$-SMA and synthesize type I collagen that contribute to the reorganization of the ECM. These specialized contracting cells exert increased traction forces that are able to pull the ECM shortening the surrounding collagen network. Due to their "synthetic" phenotype, myofibroblasts synthesize new collagen that stabilizes the surrounding collagen network. This 
phenomenon leads to not only the remodeling of the damaged ECM but also contraction of the dermis. After wound repair, TGF- $\beta 1$ is reduced, and the activity of myofibroblasts is reduced due to myofibroblast dedifferentiation to fibroblasts [11]. These findings demonstrate that the focus of new therapeutics for the treatment of excisional wounds should go beyond skin mechanics and interfere with myofibroblasts mechanobiology. In fact, Kun et al. have recently shown accelerated healing and lower scar formation of mice excisional wounds by inhibiting FAK, one of the main mediators of mechanobiology [154]. This response was associated with the reduced action of myofibroblasts and reduced collagen deposition. Despite the increasing knowledge observed in the last years in the fields of skin mechanobiology and biomechanics, the mechanobiological processes occurring in wound healing are still far from being totally understood. Better knowledge of these processes will be a breakthrough in the development of new therapies for a scarless wound healing.

\subsection{FINAL REMARKS}

The growing knowledge of skin biomechanics and skin mechanobiology has greatly contributed to understand the importance of mechanical stress in skin homeostasis and in skin wound healing. Knowledge of the importance of mechanical stress in wound healing has potentiated the creation of new therapies to counteract the wound healing forces and improve the normal skin tensegrity. In addition to the mechanical off-loading therapies, other therapies that focus on skin mechanobiology events are a pathway to follow in the future. It is clear that strategies that aim for scarless wound regeneration should consider not only the cellular and biochemical milieu of the wound healing process but also the mechanical environment. Nonetheless, the future successes will greatly depend on a better understanding of the molecular mechanisms involved in the skin response to the wound intrinsic mechanical forces as the stimuli and underlying mechanisms that drive wound healing to be elucidated.

\section{References}

[1] E.A. Gantwerker, D.B. Hom, Clin. Plast. Surg. 39 (2012) 85-97.

[2] R.A. Kamel, J.F. Ong, E. Eriksson, J.P. Junker, E.J. Caterson, J. Am. Coll. Surg. 217 (2013) 533-555.

[3] H. Oxlund, J. Manschot, A. Viidik, J. Biomech. 21 (1988) 213-218.

[4] F.H. Silver, J.W. Freeman, D. DeVore, Skin Res. Technol. 7 (2001) 18-23.

[5] K. Langer, Br. J. Plast. Surg. 31 (1978) 93-106.

[6] M.H. Alireza Karimi Ahmad Shojaei, M. Navidbakhsh, A.M. Haghi, S.J.A. Sadati, Proc. Inst. Mech. Eng. Pt L J. Mater. Des. Appl. 0 (2015) 1-8.

[7] G. Boyer, C. Pailler Mattei, J. Molimard, M. Pericoi, S. Laquieze, H. Zahouani, Med. Eng. Phys. 34 (2012) 172-178.

[8] S. Girardeau, S. Mine, H. Pageon, D. Asselineau, Exp. Dermatol. 18 (2009) 704-711.

[9] M. Hendriks, D. Brokken, W. Oomens, L. Bader, P. Baaijens, Med. Eng. Phys. 28 (2006) 259-266.

[10] A. Ni Annaidh, K. Bruyere, M. Destrade, M.D. Gilchrist, M. Ottenio, J. Mech. Behav. Biomed. Mater. 5 (2012) $139-148$.

[11] J.J. Tomasek, G. Gabbiani, B. Hinz, C. Chaponnier, R.A. Brown, Nat. Rev. Mol. Cell Biol. 3 (2002) 349-363.

[12] R. Agha, R. Ogawa, G. Pietramaggiori, D.P. Orgill, J. Surg. Res. 171 (2011) 700-708.

[13] V.W. Wong, S. Akaishi, M.T. Longaker, G.C. Gurtner, J. Invest. Dermatol. 131 (2011) 2186-2196.

[14] L.A. Barnes, C.D. Marshall, T. Leavitt, M.S. Hu, A.L. Moore, J.G. Gonzalez, M.T. Longaker, G.C. Gurtner, Adv. Wound Care (New Rochelle) 7 (2018) 47-56.

[15] W. Wang, L. Guo, Y. Yu, Z. Chen, R. Zhou, Z. Yuan, J. Biomed. Mater. Res. Part A 103 (2015) 1703-1712.

[16] T. Cherbuin, M.M. Movahednia, W.S. Toh, T. Cao, Stem Cell Rev. Rep. 11 (2015) 460-473.

[17] J.L. Balestrini, K.L. Billiar, J. Biomech. 39 (2006) 2983-2990.

[18] E.A. Lee, D.Y. Kim, E. Chung, E.A. Lee, K.S. Park, Y. Son, Cell Transplant. 23 (2014) 285-301.

[19] G. Rolin, D. Binda, M. Tissot, C. Viennet, P. Saas, P. Muret, P. Humbert, J. Biomech. 47 (2014) 3555-3561.

[20] M. Jiang, J. Qiu, L. Zhang, D. Lü, M. Long, L. Chen, X. Luo, Exp. Ther. Med. 12 (2016) 1542-1550.

[21] J.B. Schmidt, K. Chen, R.T. Tranquillo, Cell. Mol. Bioeng. 9 (2016) 55-64.

[22] Q. Shu, J. Tan, V.D. Ulrike, X. Zhang, J. Yang, S. Yang, X. Hu, W. He, G. Luo, J. Wu, Sci. Rep. 6 (2016) 1-12.

[23] J.S. Suwandi, R.E.M. Toes, T. Nikolic, B.O. Roep, Clin. Exp. Rheumatol. 33 (2015) 97-103.

[24] R. Kuang, Z. Wang, Q. Xu, S. Liu, W. Zhang, Int. J. Clin. Exp. Med. 8 (2015) 7641-7647.

[25] M.S. Chin, L. Lancerotto, D.L. Helm, P. Dastouri, M.J. Prsa, M. Ottensmeyer, S. Akaishi, D.P. Orgill, R. Ogawa, Plast. Reconstr. Surg. 124 (2009) $102-113$.

[26] S.B. Zhou, J. Wang, C.A. Chiang, L.L. Sheng, Q.F. Li, Stem Cells 31 (2013) 2703-2713.

[27] S. Aarabi, K.A. Bhatt, Y. Shi, J. Paterno, E.I. Chang, S.A. Loh, J.W. Holmes, M.T. Longaker, H. Yee, G.C. Gurtner, FASEB J. 21 (2007) $3250-3261$.

[28] G.C. Gurtner, R.H. Dauskardt, V.W. Wong, K.A. Bhatt, K. Wu, I.N. Vial, K. Padois, J.M. Korman, M.T. Longaker, Ann. Surg. 254 (2011) 217-225.

[29] J.E. Sanders, B.S. Goldstein, D.F. Leotta, J. Rehabil. Res. Dev. 32 (1995) 214-226.

[30] J.E. Bischoff, E.M. Arruda, K. Grosh, J. Biomech. 33 (2000) 645-652.

[31] M.G. Dunn, F.H. Silver, D.A. Swann, J. Invest. Dermatol. 84 (1985) 9-13. 
[32] M.J. Munoz, J.A. Bea, J.F. Rodriguez, I. Ochoa, J. Grasa, A.P. del Palomar, P. Zaragoza, R. Osta, M. Doblare, J. Biomech. 41 (2008) $93-99$.

[33] C.H. Daly, J. Invest. Dermatol. 79 (1982) S17-S20.

[34] Y. Lanir, Skin mechanics, in: Handbook of Bioengineering, McGraw-Hill Book Company, New York, 1987.

[35] M.H. Flint, A.S. Craig, H.C. Reilly, G.C. Gillard, D.A. Parry, Connect. Tissue Res. 13 (1984) 69-81.

[36] D. Gutierrez-Lemini, Engineering Viscoelasticity, 2014.

[37] A. Delalleau, G. Josse, J.M. Lagarde, H. Zahouani, J.M. Bergheau, Skin Res. Technol. 14 (2008) 152-164.

[38] S.L. Evans, C.A. Holt, J. Strain Anal. Eng. Des. 44 (2009) 337-345.

[39] R.B. Groves, S.A. Coulman, J.C. Birchall, S.L. Evans, Comput. Methods Biomech. Biomed. Eng. 15 (2012) 73-82.

[40] E. Jacquet, G. Josse, F. Khatyr, C. Garcin, Skin Res. Technol. 14 (2008) 1-7.

[41] K.H. Lim, C.M. Chew, P.C. Chen, S. Jeyapalina, H.N. Ho, J.K. Rappel, B.H. Lim, J. Biomech. 41 (2008) 931-936.

[42] J. Mahmud, C.A. Holt, S.L. Evans, J. Biomech. 43 (2010) 1002-1006.

[43] C. Flynn, A. Taberner, P. Nielsen, Biomech. Model. Mechanobiol. 10 (2011) 27-38.

[44] X. Liang, S.A. Boppart, IEEE Trans. Biomed. Eng. 57 (2010) 953-959.

[45] C. Pailler-Mattei, S. Bec, H. Zahouani, Med. Eng. Phys. 30 (2008) 599-606.

[46] R.B. Groves, S.A. Coulman, J.C. Birchall, S.L. Evans, J. Mech. Behav. Biomed. Mater. 18 (2013) 167-180.

[47] H. Frederick, Mechanosensing and Mechanochemical Transduction in Extracellular Matrix, first ed., Springer-Verlag US, 2006.

[48] W. Li, Biomed. Eng. Lett. (2015).

[49] G.L. Wilkes, I.A. Brown, R.H. Wildnauer, CRC Crit. Rev. Bioeng. 1 (1973) 453-495.

[50] X. Feng, L. Tianjian, Springer (Ed.), Introduction to Skin Biothermomechanics and Thermal Pain, 2011, pp. 85-97.

[51] P. Fratzl, K. Misof, I. Zizak, G. Rapp, H. Amenitsch, S. Bernstorff, J. Struct. Biol. 122 (1998) 119-122.

[52] H. Oxlund, J. Manschot, A. Viidik, J. Biomech. 21 (1988) 213-218.

[53] T. Gibson, R.M. Kenedi, J.E. Craik, Br. J. Surg. 52 (1965) 764-770.

[54] W. Yang, V.R. Sherman, B. Gludovatz, E. Schaible, P. Stewart, R.O. Ritchie, M.A. Meyers, Nat. Commun. 6 (2015) 6649.

[55] A. Serafinifracassini, Nature 332 (1988) 794.

[56] Y. Lanir, Y.C. Fung, J. Biomech. 7 (1974) 171-182.

[57] W.A. Wan Abas, Biomed. Mater. Eng. 4 (1994) 473-486.

[58] S. Diridollou, F. Patat, F. Gens, L. Vaillant, D. Black, J.M. Lagarde, Y. Gall, M. Berson, Skin Res. Technol. 6 (2000) $214-221$.

[59] M. Gasior-Glogowska, M. Komorowska, J. Hanuza, M. Maczka, A. Zajac, M. Ptak, R. Bedzinski, M. Kobielarz, K. Maksymowicz, P. Kuropka, S. Szotek, J. Mech. Behav. Biomed. Mater. 18 (2013) 240-252.

[60] M. Geerligs, L. van Breemen, G. Peters, P. Ackermans, F. Baaijens, C. Oomens, J. Biomech. 44 (2011) 1176-1181.

[61] A.P. Kao, J.T. Connelly, A.H. Barber, J. Mech. Behav. Biomed. Mater. 57 (2016) 14-23.

[62] M. Ottenio, D. Tran, A. Ni Annaidh, M.D. Gilchrist, K. Bruyere, J. Mech. Behav. Biomed. Mater. 41 (2015) $241-250$.

[63] O.A. Shergold, N.A. Fleck, D. Radford, Int. J. Impact Eng. 32 (2006) 1384-1402.

[64] K. Sakata, G. Parfitt, K.L. Pinder, Biorheology 9 (1972) 173-184.

[65] E.S. Wilkins, K.L. Pinder, Physiol. Chem. Phys. 11 (1979) 23-35.

[66] J.Z. Wu, R.G. Dong, W.P. Smutz, A.W. Schopper, Biomed. Mater. Eng. 13 (2003) 373-385.

[67] M.L. Crichton, X. Chen, H. Huang, M.A. Kendall, Biomaterials 34 (2013) 2087-2097.

[68] J.A. Last, S.J. Liliensiek, P.F. Nealey, C.J. Murphy, J. Struct. Biol. 167 (2009) 19-24.

[69] P.-H. Wu, D.R.-B. Aroush, A. Asnacios, W.-C. Chen, M.E. Dokukin, B.L. Doss, P. Durand-Smet, A. Ekpenyong, J. Guck, N.V. Guz, P.A. Janmey, J.S.H. Lee, N.M. Moore, A. Ott, Y.-C. Poh, R. Ros, M. Sander, I. Sokolov, J.R. Staunton, N. Wang, G. Whyte, D. Wirtz, Nat. Methods (2018).

[70] S. Cardenas-Perez, J.J. Chanona-Perez, J.V. Mendez-Mendez, G. Calderon-Dominguez, R. Lopez-Santiago, I. Arzate-Vazquez, Innov. Food Sci. Emerg. Technol. 34 (2016) 234-242.

[71] S. Vahabi, B. Nazemi Salman, A. Javanmard, Iran J. Med. Sci. 38 (2013) 76-83.

[72] N. Gavara, Microsc. Res. Tech. 80 (2017) 75-84.

[73] M.L. Crichton, B.C. Donose, X. Chen, A.P. Raphael, H. Huang, M.A. Kendall, Biomaterials 32 (2011) 4670-4681.

[74] C.A. Grant, P.C. Twigg, D.J. Tobin, Acta Biomater. 8 (2012) 4123-4129.

[75] H. Joodaki, M.B. Panzer, Proc. Inst. Mech. Eng. H 232 (2018) 323-343.

[76] G.B. Jemec, M. Gniadecka, B. Jemec, Skin Res. Technol. 2 (1996) 164-166.

[77] G. Boyer, N. Lachmann, G. Bellemere, C. Belilovsky, C. Baudouin, Skin Res. Technol. (2018).

[78] J. Ankersen, A.E. Birkbeck, R.D. Thomson, P. Vanezis, Proc. Inst. Mech. Eng. Part H J. Eng. Med. 213 (1999) $493-501$.

[79] M.F. Griffin, B.C. Leung, Y. Premakumar, M. Szarko, P.E. Butler, J. Otolaryngol. Head Neck Surg. 46 (2017) 33.

[80] L. Falland-Cheung, M. Scholze, P.F. Lozano, B. Ondruschka, D.C. Tong, P.A. Brunton, J.N. Waddell, N. Hammer, J. Mech. Behav. Biomed. Mater. 84 (2018) 188-197.

[81] F. Hendriks, Biomed. Eng. 4 (1969) 322-327.

[82] J.F. Manschot, A.J. Brakkee, J. Biomech. 19 (1986) 511-515.

[83] L. Penuela, C. Negro, M. Massa, E. Repaci, E. Cozzani, A. Parodi, S. Scaglione, R. Quarto, R. Raiteri, Exp. Dermatol. 27 (2018) $150-155$.

[84] K. Elleuch, R. Elleuch, H. Zahouani, Polym. Eng. Sci. 46 (2006) 1715-1720.

[85] Y. Zheng, A.F. Mak, IEEE Trans. Rehabil. Eng. 7 (1999) 257-267.

[86] C.Y.L. Chao, Y.-P. Zheng, Y.-P. Huang, G.L.Y. Cheing, Clin. Biomech. (Bristol, Avon) 25 (2010) 594-600.

[87] J. Isaza, J. Ramirez, 4th International Conference Tissue Engineering ICTE2015, An ECCOMAS Thematic Conference, vol. 110, (2015) pp. 45-50.

[88] D.L. Bader, P. Bowker, Biomaterials 4 (1983) 305-308.

[89] R. Grahame, P.J. Holt, Gerontologia 15 (1969) 121-139.

[90] S. Diridollou, V. Vabre, M. Berson, L. Vaillant, D. Black, J.M. Lagarde, J.M. Gregoire, Y. Gall, F. Patat, Int. J. Cosmet. Sci. 23 (2001) $353-362$.

[91] K.A. Jansen, D.M. Donato, H.E. Balcioglu, T. Schmidt, E.H.J. Danen, G.H. Koenderink, Biochim. Biophys. Acta Mol. Cell Res. 1853 (2015) 3043-3052. 
[92] C.S. Chen, J. Cell Sci. 121 (2008) 3285-3292.

[93] Y. Chen, L. Ju, M. Rushdi, C. Ge, C. Zhu, Mol. Biol. Cell 28 (2017) 3134-3155.

[94] S.J. Mousavi, M.H. Doweidar, M. Doblaré, Comput. Methods Biomech. Biomed. Eng. (2014).

[95] A.N. Gasparski, K.A. Beningo, Arch. Biochem. Biophys. 586 (2015) 20-26.

[96] S.J. Mousavi, M.H. Doweidar, PLoS One (2015).

[97] S.J. Mousavi, M.H. Doweidar, Comput. Methods Prog. Biomed. (2016).

[98] E.A. Lumpkin, M.J. Caterina, Nature 445 (2007) 858-865.

[99] A. Zimmerman, L. Bai, D.D. Ginty, Science (80-) 346 (2014) 950-954.

[100] V.Z. Luu, B. Chowdhury, M. Al-omran, D.A. Hess, S. Verma, Atherosclerosis 275 (2018) 196-204.

[101] N. Shoham, A. Gefen, J. Biomech. 45 (2012) 1-8.

[102] F. Guilak, D.M. Cohen, B.T. Estes, Cell Stem Cell 5 (2009) 17-26.

[103] M.P. Ruutu, X. Chen, O. Joshi, M.A. Kendall, I.H. Frazer, Exp. Dermatol. 20 (2011) 534-536.

[104] S. Kippenberger, A. Bernd, S. Loitsch, J. Muller, M. Guschel, R. Kaufmann, Pigment Cell Res. 12 (1999) $246-251$.

[105] S. Kippenberger, S. Loitsch, J. Müller, M. Guschel, A. Ramirez-Bosca, R. Kaufmann, A. Bernd, Pigment Cell Res. 13 (2000) $278-280$.

[106] F.H. Silver, L.M. Siperko, G.P. Seehra, Skin Res. Technol. 9 (2003) 3-23.

[107] L. Dunn, H.C.G. Prosser, J.T.M. Tan, L.Z. Vanags, M.K.C. Ng, C.A. Bursill, J. Vis. Exp. (2013) 1-6.

[108] F.E. Görmar, A. Bernd, J. Bereiter-Hahn, H. Holzmann, Arch. Dermatol. Res. 282 (1990) 22-32.

[109] M. Hara, T. Fujii, R. Hashizume, Y. Nomura, Cytotechnology 66 (2014) 723-728.

[110] R.T. Lee, W.H. Briggs, G.C. Cheng, H.B. Rossiter, P. Libby, T. Kupper, J. Immunol. 159 (1997) 5084-5088.

[111] S. Kippenberger, A. Bernd, S. Loitsch, M. Guschel, J. Müller, J. Bereiter-Hahn, R. Kaufmann, J. Invest. Dermatol. 114 (2000) $408-412$.

[112] T. Takei, C. Rivas-Gotz, C.A. Delling, J.T. Koo, I. Mills, T.L. Mccarthy, M. Centrella, B.E. Sumpio, J. Cell. Physiol. 173 (1997) $64-72$.

[113] T. Takei, H. Kito, W. Du, I. Mills, B.E. Sumpio, J. Cell. Biochem. 69 (1998) 95-103.

[114] N. Bhadal, I.B. Wall, S.R. Porter, S. Broad, G.E. Lindahl, S. Whawell, M.P. Lewis, Br. J. Dermatol. 158 (2008) 396-398.

[115] J. Zhou, J. Wang, N. Zhang, Y. Zhang, Q. Li, Am. J. Transl. Res. 7 (2015) 2187-2198.

[116] S. Yano, M. Komine, M. Fujimoto, H. Okochi, K. Tamaki, J. Invest. Dermatol. 122 (2004) 783-790.

[117] K. Nishimura, P. Blume, S. Ohgi, B.E. Sumpio, J. Surg. Res. 155 (2009) 125-131.

[118] E. Tokuyama, Y. Nagai, K. Takahashi, Y. Kimata, K. Naruse, PLoS One 10 (2015) 1-12.

[119] Y. Knies, A. Bernd, R. Kaufmann, J. Bereiter-Hahn, S. Kippenberger, Exp. Dermatol. 15 (2006) 347-355.

[120] S. Yano, M. Komine, M. Fujimoto, H. Okochi, K. Tamaki, Exp. Dermatol. 15 (2006) 356-361.

[121] S. Kippenberger, S. Loitsch, M. Guschel, J. Müller, Y. Knies, R. Kaufmann, A. Bernd, J. Biol. Chem. 280 (2005) $3060-3067$.

[122] D. Lü, X. Liu, Y. Gao, B. Huo, Y. Kang, J. Chen, S. Sun, L. Chen, X. Luo, M. Long, PLoS One 8 (2013).

[123] D. Lï, Z. Li, Y. Gao, C. Luo, F. Zhang, L. Zheng, J. Wang, S. Sun, M. Long, Biomed. Eng. Online 15 (2016) 605-620.

[124] F. Reno, V. Traina, M. Cannas, Cell Adhes. Migr. 3 (2009) 239-242.

[125] M. Kurita, M. Okazaki, T. Fujino, A. Takushima, K. Harii, Biochem. Biophys. Res. Commun. 409 (2011) $103-107$.

[126] S. Kippenberger, J. Kleemann, M. Meissner, K. Steinhorst, J. Müller, C.C. Zouboulis, R. Kaufmann, N. Zöller, J. Dermatol. Sci. 89 (2018) $241-247$.

[127] T.D. Allen, S.L. Schor, J. Ultrasructure Res. 83 (1983) 205-219.

[128] S. Manzano, R. Moreno-Loshuertos, M. Doblaré, I. Ochoa, M.H. Doweidar, Med. Biol. Eng. Comput. (2015).

[129] C.A. Lambert, A.C. Colige, C.M. Lapière, B.V. Nusgens, Eur. J. Cell Biol. 80 (2001) 479-485.

[130] A. Parekh, V.C. Sandulache, T. Singh, S. Cetin, M.S. Sacks, J.E. Dohar, P.A. Hebda, Wound Repair Regen. 17 (2009) 88-98.

[131] G.J. Fisher, Y. Shao, T. He, Z. Qin, D. Perry, J.J. Voorhees, T. Quan, Aging Cell 15 (2016) 67-76.

[132] M. Takeya, Y. Okumura, T. Nikawa, J. Physiol. Sci. 67 (2017) 613-622.

[133] M. Parsons, E. Kessler, G.J. Laurent, R.A. Brown, J.E. Bishop, Exp. Cell Res. 252 (1999) 319-331.

[134] D. Deng, W. Liu, F. Xu, Y. Yang, G. Zhou, W.J. Zhang, L. Cui, Y. Cao, Biomaterials 30 (2009) 6724-6730.

[135] Z.H. Syedain, R.T. Tranquillo, J. Biomech. 44 (2011) 848-855.

[136] E.A. Sander, V.H. Barocas, R.T. Tranquillo, Ann. Biomed. Eng. 39 (2011) 714-729.

[137] R. Kuang, Z. Wang, Q. Xu, X. Cai, T. Liu, Ann. Plast. Surg. 76 (2016) 388-393.

[138] D. Kessler, S. Dethlefsen, I. Haase, M. Plomann, F. Hirche, T. Krieg, B. Eckes, J. Biol. Chem. 276 (2001) 36575-36585.

[139] N.K. Weidenhamer, R.T. Tranquillo, Tissue Eng. Part C Methods 19 (2013) 386-395.

[140] C. Huang, K. Miyazaki, S. Akaishi, A. Watanabe, H. Hyakusoku, R. Ogawa, J. Plast. Reconstr. Aesthetic Surg. 66 (2013) e351-e361.

[141] H. Wen, P.A. Blume, B.E. Sumpio, Int. Wound J. 6 (2009) 149-158.

[142] R.T. Prajapati, M. Eastwood, R.A. Brown, Wound Repair Regen. 8 (2000) 238-246.

[143] R.T. Prajapati, B. Chavally-Mis, D. Herbage, M. Eastwood, R.A. Brown, Wound Repair Regen. 8 (2000) $226-237$.

[144] M. Kim, D.W. Shin, H. Shin, M. Noh, J.H. Shin, Exp. Dermatol. 22 (2013) 72-74.

[145] C. Viennet, J. Bride, V. Armbruster, F. Aubin, A.C. Gabiot, T. Gharbi, P. Humbert, Arch. Dermatol. Res. 297 (2005) $10-17$.

[146] A. Sarasa-Renedo, V. Tunç-Civelek, M. Chiquet, Exp. Cell Res. 312 (2006) 1361-1370.

[147] A.S. Peters, G. Brunner, T. Krieg, B. Eckes, Arch. Dermatol. Res. 307 (2015) 191-197.

[148] K. Nishimura, P. Blume, S. Ohgi, B.E. Sumpio, Wound Repair Regen. 15 (2007) 646-656.

[149] Y. Kanazawa, J. Nomura, S. Yoshimoto, T. Suzuki, K. Kita, N. Suzuki, M. Ichinose, Connect. Tissue Res. 50 (2009) $323-329$.

[150] A.S. Peters, G. Brunner, K. Blumbach, D.J. Abraham, T. Krieg, B. Eckes, Exp. Dermatol. 21 (2012) 765-770.

[151] K. Langer, Br. J. Plast. Surg. 31 (1978) 3-8.

[152] M.D. Ridge, V. Wright, J. Invest. Dermatol. 46 (1966) 341-346.

[153] A. Summerfield, F. Meurens, M.E. Ricklin, Mol. Immunol. 66 (2015) 14-21.

[154] A.A. Kun Ma, S.H. Kwon, J. Padmanabhan, D. Duscher, G.C. Trotsyuk, Y. Dong, M. Inayathullah, J. Rajadas, Gurtner, J. Clin. Invest. (2018) 1-9. 